\title{
O Desempenho Exportador do Chile: um Debate em Andamento
}

\author{
Luciano Mussa \\ Carlos Eduardo Carvalho*
}

Resumo: 0 artigo apresenta um panorama das principais questões ligadas ao desempenho das exportações no Chile nas últimas décadas. $\mathrm{O}$ objetivo principal é oferecer um quadro geral dos temas mais relevantes, em especial o debate sobre as relações entre sucesso exportador, crescimento econômico e incorporação de progresso técnico, além do papel do Estado no crescimento e diversificação das exportações. O vigoroso desempenho exportador do Chile deveria ter promovido o enobrecimento dos produtos e o desenvolvimento de atividades industriais de maior conteúdo tecnológico, mas não há evidências de que tal processo virtuoso tenha acontecido. $\mathrm{O}$ apoio persistente e diversificado do setor público às exportações desmente a visão simplificadora do Chile como exemplo de sucesso econômico promovido pelo mercado sem intervenção estatal.

Palavras-chave: Chile, Exportações, Crescimento, Progresso Técnico, Intervenção Estatal.

Abstract: The article presents a panoramic view of the main questions concerning Chilean exports performance in the last few decades. The main objective is to offer a general picture of the most important subjects, in special the debate on the relations between exporting success, economic growth and incorporation of technical progress, as well as the role of the State in the growth and diversification of the exports. Chile's vigorous exporting performance should have promoted the improvement of the products and the development of industrial activities with higher technological content, but there is no evidence that such virtuous process has happened. The persistent and diversified support of the public sector to the exports, contradicts the simplified vision of Chile as example of economic success promoted by the market without State intervention.

Keywords: Chile, Exports, Economic Growth, Technical Progress, State Intervention.

\footnotetext{
* Luciano Mussa é mestre em Economia pelo Programa de Estudos Pós-Graduados em Economia Política da Pontifícia Universidade Católica de São Paulo - PUC/SP e Professor da Universidade Metodista. E-mail: luciano.mussa@bol.com.br. Carlos Eduardo Carvalho é Professor do Departamento de Economia da PUC/SP. E-mail: cecarv@uol.com.br. Recebido em 14/05/07 e aceito em 12/06/07.
} 
O artigo é versão resumida da dissertação de Mestrado de Luciano Mussa "Um estudo sobre as exportaçóes chilenas a partir das reformas liberalizantes dos anos 1970", defendida em novembro de 2006, sob orientação do Professor Carlos Eduardo Carvalho. Agradecemos as críticas, comentários e sugestóes de Maria Cristina Cacciamali, Patrícia Helena Fernandes Cunha e aos pareceristas anônimos da Revista Cadernos PROLAM/USP.

\section{Introdução}

O vigoroso desempenho das exportaçóes é apontado como um dos principais fatores responsáveis pelo vigoroso crescimento da economia chilena a partir de meados da década de 1980. O fluxo de divisas gerado pelas vendas externas estimulou a economia, financiou o salto das importaçóes e preservou o país das piores conseqüências das crises externas que afetaram a América Latina. Houve importante diversificação de produtos, de destinos e de empresas envolvidas. Quanto à indução de ganhos de produtividade e de incorporação de progresso técnico, contudo, os resultados são insuficientes. A ênfase em exportaçóes deveria ter promovido o enobrecimento dos produtos e o desenvolvimento de atividades industriais de maior conteúdo tecnológico hacia atrás y hacia adelante, mas não há evidências de que esse processo virtuoso tenha acontecido em escala relevante.

Outra questão de grande interesse é o papel decisivo do Estado no sucesso exportador do Chile, com a criação de importantes instrumentos de fomento e apoio às empresas logo após o golpe militar de 1973 e com a orientação da política econômica para a ênfase exportadora, depois da gravíssima crise de 1981-83. O apoio persistente e diversificado do setor público às exportaçóes desmente a visão simplificadora do Chile como exemplo de sucesso econômico devido à ausência de intervenção do setor público na economia.

$\mathrm{O}$ artigo apresenta um panorama das principais questôes ligadas ao desempenho das exportaçóes no Chile nas últimas décadas. O objetivo principal é oferecer um quadro amplo dos temas mais relevantes, em especial o debate sobre as relaçóes entre sucesso exportador, crescimento econômico e incorporação de progresso técnico, bem como sobre o papel do Estado no desenvolvimento das exportaçóes e das empresas exportadoras.

Além desta introdução e das notas finais, o artigo se divide em três seçôes. 
A primeira faz uma resenha do debate sobre exportaçóes e crescimento econômico, de modo a situar a indagação sobre a consistência do êxito chileno, em especial sobre a capacidade de induzir a incorporaçáo de progresso técnico. A segunda seçáo traça um panorama geral das exportaçóes chilenas nas últimas décadas, destacando alguns casos notáveis e a questão da incorporação de tecnologia. A terceira apresenta um panorama do quadro econômico e da ação estatal em prol das exportaçóes e das empresas exportadoras, tanto nas políticas macroeconômicas quanto nos instrumentos de apoio.

\section{Exportações e crescimento: algumas referências teóricas}

Os diferentes enfoques teóricos sobre as relações entre exportaçóes e crescimento econômico destacam três aspectos particularmente relevantes para a análise do caso chileno: a contribuição para a elevação da produtividade e a incorporação de tecnologia; a melhoria da posição cambial, ou seja, melhora no balanço de pagamentos e na capacidade de sustentaçáo do fluxo de importaçóes; e o estímulo à demanda agregada. Merece especial destaque o problema da incorporação de progresso técnico como critério para a avaliação dos efeitos do incremento das exportaçóes, tendo em vista que o tipo de produto exportado influi muito no grau de crescimento da economia. Dito de forma simplificada, se as exportaçóes são o motor do crescimento econômico, é desejável que o tipo de produto exportado seja o melhor possível - que gere mais divisas e, principalmente, que estimule o desenvolvimento tecnológico e a elevação da produtividade da economia.

As recentes teorias do crescimento dão grande importância ao conhecimento tecnológico e sua incorporação à atividade produtiva, como fator de crescimento econômico dos países, e há um consenso em torno do papel atribuído ao progresso técnico de cada país como fonte principal das assimetrias internacionais, expressas na divergência entre taxas de crescimento de longo prazo. Estas novas teorias trazem à discussão uma tese que foi central na concepção centro-periferia da visão inicial da CEPAL nos anos 1950, a tese do caráter bipolar do desenvolvimento econômico na economia internacional. 


\section{Tecnologia, crescimento, instituições}

As versões tradicionais dos modelos de crescimento neoclássicos ${ }^{1}$ partem de uma função de produção com rendimentos constantes de escala e rendimentos decrescentes de cada fator, que são capital e trabalho. O caráter decrescente da produtividade marginal do capital desestimula o investimento a partir do equilíbrio determinado pelo estado estacionário. Assim, na ausência de progresso técnico, a taxa de crescimento de longo prazo do PIB por habitante tenderá a zero. No longo prazo, o investimento servirá apenas para cobrir a depreciação do capital existente e equiparar a nova mão-deobra adicionada à produção. Assim, se caracteriza um estado de crescimento estável (steady-growth), no qual o produto cresce no mesmo ritmo que a taxa da população ativa. No modelo de Solow, o crescimento sustentado ocorre apenas quando há progresso tecnológico; sem ele, a acumulação de capital entra na fase dos rendimentos decrescentes; na presença dele, as melhoras na tecnologia compensam os efeitos dos retornos decrescentes sobre a acumulação de capital (JONES, 2000, p. 30). O caráter exógeno refere-se justamente ao fato de que um ritmo de crescimento maior só será alcançado mediante uma mudança tecnológica exógena ao sistema.

Os novos modelos de crescimento endógeno neoclássicos destacam a inovação intencional. $\mathrm{O}$ modelo de Romer torna endógeno o progresso tecnológico ao introduzir a busca de novas idéias por pesquisadores interessados em obter lucros com novas invençóes. Para Hounie et al. (1999), os modelos endógenos consideram que na realidade não existem oportunidades tecnológicas à disposição de todos, de forma homogênea, que possam levar à convergência. Assim, destaca-se a importância do efeito da difusão tecnológica.

$\mathrm{Na}$ ótica evolucionista, o processo de geração, adaptação e difusão do conhecimento se torna ainda mais complexo, devido ao caráter acumulativo do conhecimento tecnológico. O desenvolvimento institucional se torna chave e o progresso técnico assume a função de determinar a competitividade dos países, condicionando a taxa de crescimento de longo prazo mediante a demanda dos distintos bens. Hounie et al. (1999) citam o modelo de

\footnotetext{
${ }^{1}$ A referência básica é o trabalho de Solow (1956).
} 
Verspagen ${ }^{2}$, o qual dá especial relevância aos hiatos tecnológicos e às capacidades internas de aprendizado. Este modelo supóe uma assimetria de competitividade entre o norte e o sul. A menor competitividade do sul leva a um menor dinamismo da demanda e a um menor estímulo ao crescimento. O resultado global sobre o crescimento dependerá do sentido e da intensidade com que operem os efeitos competitividade e difusão tecnológica:

O progresso técnico nos países do sul é uma função não linear do nível inicial do hiato tecnológico. Até determinado ponto, a existência do hiato favorece o progresso técnico do sul mediante as possibilidades de imitação. Porém, se o hiato for muito grande, a difusão se torna mais difícil, pois a capacidade de imitar diminui com a distância em relação à capacidade tecnológica. (HOUNIE et al., 1999, p. 16)

Em tese, a abertura comercial tem alguns efeitos positivos: i) a maior interação das empresas locais com firmas e mercados externos permite um maior intercâmbio de tecnologia e práticas de administração; ii) ao estarem expostas a um maior grau de competição externa, as empresas locais têm que incrementar as eficiências técnicas, ou pelo menos reduzir as ineficiências; iii) gera maior especialização e aproveitamento das economias de escala, devido à expansão do mercado.

Em outras palavras, a intensidade da imitação depende das capacidades internas de aprendizagem, ou seja, de uma base institucional interna. Neste ponto, fica fácil perceber que as políticas públicas têm um papel importante nestes modelos. Os teóricos dos modelos agregados consideram a incidência do progresso técnico sobre a produtividade dos recursos e sobre a competitividade internacional, que condicionam a taxa de crescimento através da demanda efetiva. Isto significa que estes modelos supóem que a taxa de crescimento de longo prazo de um país será compatível com o equilíbrio do balanço de pagamentos associado às elasticidades-ingresso da demanda de exportaçóes e importaçóes, corrigidas pela disponibilidade de recursos internacionais para financiamento. Estas variáveis determinam o comportamento da demanda nos mercados interno e externo (HOUNIE et al., 1999, p. 16).

\footnotetext{
${ }^{2}$ Verspagen, B. Uneven growth between interdependent economies, Adershot, Reino Unido, Avebury, 1993.
} 
Em suma, o modelo não considera a idéia otimista de que um hiato tecnológico conduziria, de maneira automática, a uma difusão tecnológica mais rápida. Esta convergência depende das capacidades institucionais e tecnológicas locais. Por outro lado, o valor estável do hiato não garante convergência das taxas de crescimento, se a diferença nos níveis de produtividade é mantida. Assim, o caminho para a convergência seria a aceleração do processo inovador autônomo no sul.

\section{O papel da demanda e da restrição cambial}

Diferentemente dos neoclássicos, cuja teoria do crescimento é orientada pela oferta, há uma outra visão alternativa que considera de fundamental importância a demanda por exportação como sendo o mais importante componente de demanda autônoma na economia aberta. Neste caso, o crescimento das exportaçóes irá governar o crescimento de longo prazo da produção. Esta visão, originária do keynesianismo, procura analisar quais são as maiores restriçóes que podem prejudicar a demanda e assume que estas restriçóes de demanda geralmente agem antes das restriçóes de oferta, sendo portanto mais perigosas. Considera ainda que a teoria neoclássica ignora o fato de que o crescimento da produtividade também pode ser uma função da pressão da demanda na economia. Thirlwall (2002), um dos representantes dessa escola de origem keynesiana, acrescenta que as exportaçóes diferem dos outros componentes de demanda por três importantes motivos:

Firstly, exports are the only true component of autonomous demand in an economic system, in the sense of demand emanating from outside the system. [..] The major part of consumption and investment demand is dependent on the growth of income itself. Secondly, exports are the only component of demand that can pay for the import requirements for growth. It may be possible to initiate consumption-led growth, investment-led growth or government expenditure-led growth for a short time, but each of these components of demand has an import content $[\ldots]$. [...] The third important aspect of exports is that imports (permitted by exports) may be more productive than domestic resources because certain crucial goods necessary for development (such as capital goods) are not produced domestically. (THIRLWALL, 2002, p. 53-54) 
Quando não há receitas geradas pelas exportaçóes para pagar pelas importaçóes, a demanda tem que ser restringida. Além disso, quando o equilíbrio no balanço de pagamentos é um requerimento de longo prazo, as exportaçóes são bastante importantes. Problemas no balanço de pagamentos podem gerar restriçáa ao crescimento da demanda e, portanto, ao crescimento do produto:

In an open economy, the major constraint on the growth of demand (and therefore growth performance) is likely to be its balance of payments. At a theoretical level, it can be stated as a fundamental proposition that no country can grow faster than that rate consistent with balance of payments equilibrium on current account unless it can finance evergrowing deficits, which, in general, it cannot. (THIRLWALL, 2002, p. 66)

Se os fluxos de capital (que às vezes podem financiar eventuais déficits) são incluídos no modelo, pode-se dizer que todo país deve ter uma taxa de crescimento consistente com o seu balanço de pagamentos.

At the empirical (observational) level, the evidence for the proposition I am making is that many countries find themselves in balance of payments difficulties, and have to constrain growth, while the economy still has surplus capacity and surplus labour. (THIRLWALL, 2002, p. 67)

Conforme assinalam Hounie et al. (1999), a CEPAL vem incorporando as novas teorias de crescimento econômico em seus estudos, em especial as teorias evolucionistas, com grande destaque para a competitividade internacional, a incorporação de progresso tecnológico e do conhecimento, bem como a importância das exportaçóes para a sustentação da demanda e da solvência externa. Vale ressaltar que estes itens se relacionam entre si.

Um crescimento a longo prazo só será sustentável à medida que uma economia for capaz de aumentar ou ao menos manter sua participação nos mercados internacionais, com crescimento simultâneo do nível de vida da população. O progresso tecnológico é, sem dúvida, chave neste processo. Uma inserção internacional depende também dos aspectos relacionados ao 
conhecimento, como a contínua renovação da eficiência no uso dos recursos ou a capacidade de agregar valor aos bens e serviços produzidos. $\mathrm{O}$ rápido crescimento das exportaçóes exige a diversificação dos bens e mercados, favorecendo os produtos mais dinâmicos, que em geral são os que contêm maior valor agregado e maior conteúdo tecnológico. A estrutura exportadora é outro elemento essencial para o aumento da produtividade e do produto no longo prazo. Isto envolve os sistemas produtivos, de transporte, de comercialização e de financiamento. As políticas públicas entram neste contexto com a função de corrigir imperfeições nos mercados de tecnologia e de capital humano.

\section{Abertura comercial e pauta de exportações}

Para o modelo de crescimento tradicional de Solow, o comércio irá afetar o nível de equilíbrio da produção agregada, mas não a taxa de crescimento. Com o desenvolvimento dos modelos de crescimento endógenos, essa visão foi alterada, a fim de mostrar os efeitos das políticas comerciais no crescimento econômico. Há algumas importantes vantagens dinâmicas do livre comércio que afetam a produtividade e o crescimento, mesmo no longo prazo.

Edwards (1993) cita o trabalho de $\mathrm{Krueger}^{3}$ que, usando dados de estudos individuais de países, testou econometricamente duas hipóteses: i) regimes mais liberais resultam em maiores taxas de crescimento das exportaçóes; e ii) setor de comércio mais liberalizado tem um efeito positivo no crescimento agregado. No último caso, a abertura afeta positivamente o crescimento por dois canais. Primeiro, há efeitos diretos que operam via vantagens dinâmicas, incluindo maior utilização da capacidade e projetos de investimento mais eficientes. Segundo, há efeitos indiretos que operam através das exportações: economias mais liberalizadas têm um crescimento mais rápido das exportaçóes e estas, por sua vez, resultam num crescimento mais rápido do PIB.

Hausmann, Hwang e Rodrik (2006) afirmam que a política governamental tem uma participação importante na definição da estrutura produtiva de um país, ao lado dos fundamentos, ou seja, capitais físico e humano, trabalho, recursos humanos e a qualidade geral de suas instituiçôes. A análise dos

\footnotetext{
${ }^{3}$ Krueger, Anne O. Foreign trade regimes and economic development: liberalization attempts and consequences. Cambridge, MA: Ballinger Pub. Co. for NBER, 1978.
} 
autores é baseada no "custo de descoberta":

An entrepreneur who attempts to produce a good for the first time in a developing country necessarily faces considerable cost uncertainty. [...] If the project is successful, other entrepreneurs learn that the product in question can be profitably produced and emulate the incumbent. In this way, the returns to the pioneer investor's cost discovery become socialized. If the incumbent ends up with failure, on the other hand, the losses remain private. This knowledge externality implies that investment levels in cost discovery are sub-optimal unless the industry or the government find some way in which the externality can be internalised. (HAUSMANN, HWANG, RODRIK, 2006, p. 2)

Para os autores, alguns produtos comercializáveis são associados com níveis de produtividade mais altos, países que produzem mercadorias com maior grau de produtividade terão performance superior e o tipo de produto exportado influi na taxa de crescimento de um país, principalmente nos países de renda média. Países que exportam produtos associados com níveis de produtividade mais altos crescem mais rapidamente. $\mathrm{O}$ crescimento é o resultado da transferência de recursos das atividades com baixa produtividade para as de alta produtividade, identificadas pelo processo de custo de descoberta do empreendedor. Portanto, a política governamental necessária é a do subsídio para os empreendedores que investem em novas atividades, mas não para os seguidores, que já farão uso das externalidades geradas.

Palma (2005) também destaca a importância do tipo de produto exportado no crescimento econômico, além de analisar se a dinâmica regional é um componente importante da probabilidade de países menos desenvolvidos exportarem um ou outro tipo de produto. Sobre o primeiro ponto, o autor chega à conclusão de que as disparidades econômicas vinculadas ao tipo de produto exportado pelos países são substanciais, tanto com relação à oferta quanto à demanda. No que diz respeito à oferta, percebe-se que "alguns produtos de exportação parecem ter uma capacidade maior de gerar um crescimento do PIB induzido pelo comércio exterior do que outros”. Já sob a ótica da demanda, "a maior diferença surge do fato de a demanda internacional por algumas categorias de produtos (produtos com alto ou 
médio conteúdo tecnológico e alguns produtos de origem natural em estágio avançado da cadeia de valor adicionado) ter crescido muito mais rapidamente do que a demanda por outros (produtos de baixo conteúdo tecnológico e produtos de origem natural com baixo grau de processamento)" (PALMA, 2005, p. 394).

Quanto à segunda questão, "existem evidências apontando para o fato de que a dinâmica regional pode ter um papel de destaque no perfil exportador dos países menos desenvolvidos" (PALMA, 2005, p. 395). Os dados analisados pelo autor sugerem que o crescimento muito superior do Leste Asiático, quando comparado com a América Latina, nas últimas décadas, "está diretamente associado a seu esforço continuado, tanto por parte do governo como do setor industrial, de agregar valor à oferta e adaptar à demanda externa sua pauta de exportação" (PALMA, 2005, p. 395).

Durante a segunda metade do século XX, os países do Leste Asiático elevaram maciçamente tanto seu percentual de exportaçóes como de produtos manufaturados no PIB. Por contraste, a América Latina teve uma significativa redução da participação das exportações no PIB. Esta queda foi conseqüência da demanda fraca por produtos primários nos mercados da OCDE. Uma diferença importante entre as exportaçóes da América Latina e do Leste Asiático encontra-se em seu diferente grau de competitividade, medido como a capacidade de elevar sua participação nas importaçóes da OCDE. O problema das exportaçóes latino-americanas parece ser cada vez menos de competitividade em seus produtos de exportação tradicionais, e cada vez mais um problema de incapacidade de se reinventar, ou seja, de se adaptar à demanda e aprimorar a oferta, de maneira a serem capazes de beneficiar-se mais efetivamente de um ambiente institucional e tecnológico em mudança permanente.

As estatísticas mostram que, entre 1963 e 2000, os produtos primários não petrolíferos "perderam em torno de três quartos de sua participação nas importaçóes da OCDE, caindo de 41,1\% para 10,6\%. [...] Por contraste, as importações de máquinas e equipamentos mais do que dobraram sua participação em importaçóes da OCDE durante este mesmo período (de 18,4\% para 41\%)" (PALMA, 2005, p. 41). 
[...] num sentido ricardiano, a própria elevação da eficiência exportadora da regiáo pode agir às vezes como um "gol contra", porque a elevaçáo de competitividade pode ajudar o crescimento do PIB - mas se for em detrimento dos termos de troca, pode não colaborar muito para a elevaçáo do poder de compra deste crescimento do PIB (ou seja, o padráo de vida, que depende da produção interna mas também de seu poder de compra em relação às importaçôes, pode até cair, já que em casos limite o crescimento doméstico pode ser mais do que compensado pela queda dos termos de troca) (PALMA, 2005, p. 420).

Rodrik (2001) enfatiza que comparaçóes cross-national revelam que não há relação sistemática entre o nível de restrições tarifárias e não tarifárias impostas por um país e sua taxa de crescimento. Para exacerbar o argumento, compara Vietnam e Haiti para ressaltar que a integração com a economia mundial costuma ajudar, mas não é um pré-requisito para uma estratégia de crescimento de sucesso. No Vietnam o Estado tem forte participação na economia, há grandes restriçóes às importaçóes, com altos impostos de importação (variando entre 30 e 50\%) e o país não é membro da Organização Mundial do Comércio. O Haiti é membro da OMC, diminuiu os impostos de importação para um máximo de 15\% e removeu todas as restriçóes quantitativas. Como se sabe, o Vietnã apresentou nos últimos anos taxas de crescimento acima de $8 \%$ ao ano, reduziu consideravelmente a pobreza e atraiu significativo montante de investimento externo, enquanto o Haiti estagnou e praticamente não recebe investimentos externos nem participa do comércio mundial.

Os tigres asiáticos combinaram comércio com políticas heterodoxas subsídios para exportação, ligações entre importação e exportação, desrespeito à patentes e copyright, restriçóes ao fluxo de capitais (incluindo investimento direto estrangeiro). $\mathrm{O}$ autor argumenta que o mais influente mecanismo que relaciona comércio com crescimento nos países em desenvolvimento é que o capital de produção importado costuma ser significativamente mais barato que o produzido domesticamente. Portanto, políticas que restringem a importação de máquinas e equipamentos aumentam o preço dos bens de produção, reduzindo desta forma o nível de investimento real.

$\mathrm{O}$ autor conclui que as exportaçóes são importantes pois permitem a 
compra desses bens de produção. Entretanto, é igualmente verdadeiro que praticamente nenhum país se desenvolveu simplesmente abrindo sua economia ao comércio e investimento internacional. Desta forma, uma profunda liberalização do comércio não pode ser responsável em obter altas taxas de crescimento econômico e não merece a alta prioridade que geralmente recebe nas estratégias de desenvolvimento, por parte das organizações multilaterais.

\section{As exportações chilenas}

A orientação exportadora adotada pelo Chile nas últimas décadas procurou dar conta de dois desafios: (i) diversificar as exportações, tradicionalmente concentradas em produtos minerais, em especial o cobre, ampliando os itens exportados, os mercados de destino e o número de empresas exportadoras; (ii) induzir a incorporação de tecnologia e o progresso técnico a partir dos efeitos dos segmentos exportadores sobre o conjunto da economia, em especial seus fornecedores e prestadores de serviços. Esta seção discute os resultados obtidos nestes dois desafios.

\section{Desempenho exportador e diversificação de produtos, empresas e destinos}

Nas últimas décadas, o Chile tornou-se um país comercialmente aberto, com a relação exportação/PNB acima de 20\% desde 1983 (Gráfico 1). 


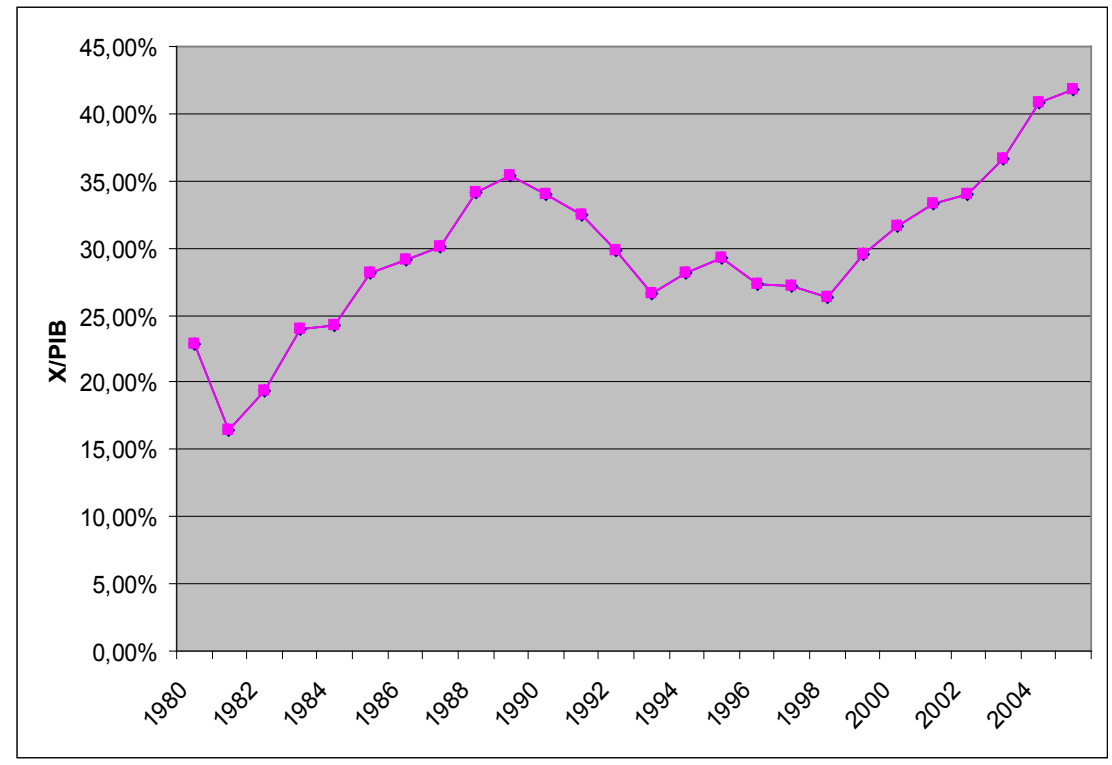

Gráfico 1 - Chile: exportaçóes de bens e serviços em relação ao PNB (\%) - 1980 a 2006 FONTE: World Perspective Monde, 2007

Houve significativa diversificação nos últimos anos. Em 1968-73 a mineração (cobre, ferro, salitre, iodo, prata, ferromolibdeno) respondia por aproximadamente $87 \%$ do valor das exportaçóes, sendo $76 \%$ do cobre, e nenhum outro setor tinha mais que 5\%. ${ }^{4}$ Pouco depois da crise do início dos anos 80, essa situação já havia se modificado (GLAUSER, 1989, p. 165). Assim, em 1984-86 cinco setores geravam, cada um, mais de 5\% do valor conjunto das exportaçóes de bens e serviços não financeiros:

i)Produtos do mar: com média de 10,2\% (composto principalmente por pescados, mariscos e algas; suas conservas; farinha e azeite de pescado; e agar-agar) ${ }^{5}$

ii)Frutas: com média de 8,8\% (composta fundamentalmente por frutas frescas, secas e em conservas; seus sucos e preparados; e vinho);

\footnotetext{
${ }^{4}$ Para uma análise da importância do cobre na economia chilena durante a ditadura, ver MELLER (1988).

5 "La capacidad extractiva pesquera se acrecentó en 11\% durante 1974-80 y además hubo una serie de mejoras tecnológicas: métodos más modernos de prospección, mayor tamaño de los barcos, mejores programas operativos, etc." (VIGNOLO, 1983).
} 
iii)Florestais: com média de 7,9\% (inclui madeiras; móveis e outras manufaturas de madeira; celulose, papéis, cartôes e impressos; e outros produtos silvícolas);

iv) "Outros serviços": com média de 6,9\% (incluiu comissôes pagas por empresas estrangeiras a casas comerciais e outros agentes econômicos chilenos; processamento e manutenção de bens; correios e telecomunicaçôes; transporte e seguros; aluguel de imóveis; e os serviços de informática, pesquisas, consultoria, administrativos, culturais, esportivos e outros que não pertencem às outras categorias de serviços não financeiros); $\mathrm{e}$

v)Transporte internacional de bens: com média de 5,6\% (constituído por fretes, seguros e serviços marítimos, portuários, de aeroportos, de locação de veículos e outros prestados a não residentes e relacionados com o transporte de bens).

$\mathrm{Na}$ Tabela 1 vê-se que, apesar da diversificação, as exportações chilenas continuam baseadas no uso intensivo de recursos naturais, mesmo no setor de manufaturas, que engloba diversos bens industriais (ALVAREZ, LEMUS, 2001). ${ }^{6}$

Tabela 1 - Exportaçóes chilenas, itens selecionados, 2005 (USD)

\begin{tabular}{|l|c|c|}
\hline \multicolumn{1}{|c|}{ Produto } & $\begin{array}{c}\text { Valor fob exportado em } \\
\text { USD (milhóes) }\end{array}$ & $\begin{array}{c}\text { Participaçáo sobre o } \\
\text { volume exportado }\end{array}$ \\
\hline Farinha de pescado & 446 & $1 \%$ \\
\hline Florestal e móveis de madeira & 1.807 & $5 \%$ \\
\hline Frutas (1) & 2.138 & $5 \%$ \\
\hline Moluscos e crustáceos & 281 & $1 \%$ \\
\hline Oxido y ferromolibideno & 3.261 & $8 \%$ \\
\hline Papel e celulose & 1.662 & $4 \%$ \\
\hline Produtos químicos (2) & 2.835 & $7 \%$ \\
\hline Salmáo e truta & 1.657 & $4 \%$ \\
\hline Vinho & 882 & $2 \%$ \\
\hline
\end{tabular}

(1) O Chile é especializado na produção e exportação de diversas frutas como por exemplo, uva, maçã, pêra, kiwi, nectarina, pêssegos, etc.

(2) Os principais produtos são metanol (USD 611 milhóes) e nitrato de potássio (USD 161 milhóes).

FONTE: Banco Central do Chile

\footnotetext{
${ }^{6}$ As preocupações com a preservação dos recursos naturais levou, na década de 1990, à criação de normas para o uso do meio ambiente e à promulgação da Lei 9.300, de Bases del Medio Ambiente, seguida por diversas regulamentações específicas (COCHILCO, 2004).
} 
A Tabela 2 mostra o ritmo de crescimento do quantum das exportaçóes por grandes setores selecionados. Nos quinze anos de 1986 a 2001, o crescimento cada vez mais forte do cobre contrasta com o declínio progressivo da taxa de expansão das exportaçóes dos demais produtos, inclusive do setor não tradicional.

Tabela 2 - Chile: crescimento médio anual do quantum de exportaçóes, 1961-2001, períodos selecionados

\begin{tabular}{|l|c|c|c|c|c|c|}
\hline & $\mathbf{1 9 6 1 - 7 0}$ & $\mathbf{1 9 7 1 - 7 3}$ & $\mathbf{1 9 7 4 - 8 5}$ & $\mathbf{1 9 8 6 - 8 9}$ & $\mathbf{1 9 9 0 - 9 5}$ & $\mathbf{1 9 9 6 - 2 0 0 1}$ \\
\hline Cobre & 3,9 & $-2,3$ & 5,0 & 3,3 & 6,5 & 11,4 \\
\hline Não cobre & 7,8 & $-8,5$ & 15,8 & 13,1 & 11,2 & 7,0 \\
\hline Tradicional & nd & nd & nd & 9,0 & 7,7 & 2,9 \\
\hline Não tradicional & nd & nd & nd & 21,7 & 15,2 & 10,3 \\
\hline & & & & & & \\
\hline Total Exportaçóes & 4,9 & $-4,5$ & 9,3 & 8,8 & 9,2 & 8,8 \\
\hline
\end{tabular}

Nota: Exportaçóes fob.

FONTE: Saéz (1991) para 1960-85; Banco Central de Chile para 1985-01 apud FFRENCH-DAVIS (2002a, p. 152).

Por outro enfoque, o Chile obteve grande êxito na década de 1990 na diversificação de produtos, abertura de novos mercados e ampliação do universo de empresas exportadoras:

Entre 1990 y 2002, el número de productos exportados aumentó de 2.300 a 3.750, el de mercados de destino se elevó de 129 a 158 y el de empresas exportadoras de 4.100 a 6.188. Estos indicadores de desempeño exportador son sustancialmente mejores que los de décadas anteriores (ÁLVAREZ, 2004, p. 124).

Ainda assim, as exportaçóes continuam concentradas em poucos mercados, poucos produtos e em um número reduzido de empresas. A Tabela 3 mostra que 25 empresas eram responsáveis por quase metade das exportaçóes em 2002; se adicionadas as empresas que exportam entre 10 e 100 milhóes de dólares, menos de 4\% das empresas concentravam 80\% das exportaçôes totais (ÁLVAREZ, 2004; MACARIO, 1998). Vale observar que o universo de pequenas empresas exportadoras é amplo: 3.656 empresas 
exportaram até US\$100 mil e 1.483 empresas exportaram entre US\$100 mil e US\$ 1 milhão, em 2002.

Tabela 3 - Chile: empresas exportadoras por valor exportado - número e participação no valor ex portado, 2002

\begin{tabular}{|l|c|c|c|c|}
\hline Valor exportado (dólares) & $\begin{array}{c}\text { No de } \\
\text { empresas }\end{array}$ & $\begin{array}{c}\text { \% de } \\
\text { empresas }\end{array}$ & $\begin{array}{c}\text { Exportaçóes } \\
\text { (milhóes de dólares) }\end{array}$ & $\begin{array}{c}\text { \% das } \\
\text { exportaçóes }\end{array}$ \\
\hline Menos de 100.000 & 3.656 & 59,8 & 78,2 & 0,4 \\
\hline Entre 100.000 e 1 milhão & 1.483 & 24,2 & 540,9 & 3,1 \\
\hline Entre 1 e 10 milhóes & 757 & 12,4 & $2.474,8$ & 14,2 \\
\hline Entre 10 e 100 milhóes & 197 & 3,2 & $5.773,7$ & 33,1 \\
\hline Mais de 100 milhóes & 25 & 0,4 & $8.562,6$ & 49,1
\end{tabular}

FONTE: ProChile (2002) apud ÁLVAREZ, 2004, p. 125.

Alvarez e Fuentes (2003) defendem que o Chile não se tornou uma economia menos industrializada depois da abertura, embora a composição da indústria manufatureira tenha se alterado em favor de setores intensivos em recursos naturais. Alvarez e Lemus (2001) destacam que houve bastante diversificação nas exportações (aumento do número de produtos exportados, mercados de destino e empresas exportadoras) até o fim dos anos 1980, mas com uma tendência ao aumento da concentração na década seguinte:

[...] durante los años noventa este proceso de diversificación ha ido aparentemente decayendo. Existe alguna evidencia al respecto, si se considera que la tasa de incorporación de nuevos productos y empresas exportadoras ha tendido a reducirse. Entre 1990 y 1994, las firmas exportadoras se incrementaron en un 42,5\%, entre 1995 y 1999 , aumentaron sólo en un 3,5\%. Los productos exportados pasaron de aumentar en un 57,5\% entre 1990 y 1994, a incrementarse en 3,9\% entre 1995 y 1999 (ALVAREZ, LEMUS, 2001, p. 3).

Agosin (1999) fez um estudo econométrico para tentar explicar o aumento das exportaçóes manufatureiras. Para tanto ele analisou, pelo lado da oferta, o papel de distintos fatores, como baixa nas tarifas de importação, depreciação do câmbio real e capacidade ociosa. A conclusão a que ele chega é que os fatores acima induzem mudanças positivas na oferta de exportaçóes manufatureiras, mas não afetam a tendência na sua taxa de crescimento. 
Além das alteraçóes na pauta de exportaçóes, houve mudanças também nos países de destino. Tradicionalmente, a União Européia foi o destino mais importante das exportaçóes chilenas. Em 1970, por exemplo, sua participação foi de 61\%; já em 1998 sua participação caiu bastante, absorvendo 28,2\%. Com o passar do tempo, foram ganhando importância os mercados das Américas do Norte e Latina.

La composición de la canasta de las exportaciones chilenas varía notablemente según su destino geográfico. [...] en las exportaciones destinadas a países industrializados los recursos naturales procesados y en bruto tienen una participación mucho mayor que en aquéllas dirigidas a los mercados de la región. En un marcado contraste, en 1998 las manufacturas constituyeron el $56 \%$ de las exportaciones totales de Chile a América Latina - bastante más que el 21\% registrado en 1989. [...] La enorme importancia de los mercados latinoamericanos como destino de productos manufacturados puede resultar crucial para la expansión del volumen y calidad de las exportaciones chilenas. (FFRENCH-DAVIS, 2002a, p. 155-156)

Para Alvarez e Lemus (2001), apesar da incorporação de novos mercados, persiste a concentração em número reduzido de países e participação dos cinco mercados de destino mais importantes é sempre muito próxima a 50\% (Tabela 4).

Tabela 4 - Participação por mercados de destino principais

\begin{tabular}{|c|c|c|c|c|c|}
\hline Período & 5 países & $\mathbf{1 0}$ países & $\mathbf{1 5}$ países & 20 países & 25 países \\
\hline $1960-1973$ & 51,6 & $\mathbf{7 8 , 2}$ & $\mathbf{9 0 , 8}$ & $\mathbf{9 3 , 3}$ & $\mathbf{9 7 , 7}$ \\
\hline $1974-1980$ & 47,0 & 70,1 & 81,3 & 89,5 & $\mathbf{9 2 , 1}$ \\
\hline $1981-1990$ & 47,7 & 68,0 & 81,6 & 87,8 & 89,9 \\
\hline $1991-1999$ & 48,9 & 66,3 & 81,3 & 87,3 & 89,9 \\
\hline
\end{tabular}

FONTE: Alvarez, Lemus, 2001, p. 12 


\section{Exportações e incorporação de progresso técnico: notas sobre três setores primários}

A estratégia de crescimento com ênfase nas exportaçóes enfatizou a necessidade de desenvolvimento das cadeias produtivas anteriores (insumos e equipamentos) e posteriores (produtos elaborados) nos recursos naturais (DÍAZ, 1996, p. 275-281). Enquanto as primeiras deveriam transformar o país em produtor relevante de insumos e equipamentos, com aumento da produtividade geral da indústria, as segundas induziriam a diversificação das exportaçóes, com peso crescente produtos com maior valor agregado na pauta.

El principal desafío que presenta la dinámica exportadora es su persistente concentración en recursos naturales y productos derivados, lo que determina una mayor vulnerabilidad en la demanda, por la concentración en pocos rubros, la presencia de ciclos en sus precios y limitadas posibilidades de crecimiento sostenido en función de la elasticidad-ingreso de este tipo de productos. Asimismo, se vinculan a este tipo de productos preocupaciones ambientales, que resultan cada vez más sensibles en el ámbito del comercio internacional. En el proceso de la reestructuración de los últimos 30 años es posible, de todos modos, apreciar una reorientación de las exportaciones, desde los recursos naturales hacia productos con mayor elaboración" (SILVA, 2001, p. 11).

A produção de salmão em cativeiro, por exemplo, apresenta muitos eslabonamientos hacia atrás positivos, ao estimular indústrias produtoras de jaulas flutuantes, alimentos, redes de pesca, materiais de embalagem e serviços de transporte. Além disso, por empregar profissionais altamente qualificados (engenheiros, biólogos, etc.), contribui para a demanda nos setores de construção, educação e comércio na região produtora (AGOSÍN, 1999). Diaz (1996) concorda que a expansão das atividades primário-exportadoras continuará gerando impulsos industrializantes por eslabonamientos tanto hacia adelante (por exemplo: celulose, mas não necessariamente papel), quanto hacia atrás (por exemplo: estruturas metálicas, mas não necessariamente bens de capital). 
O desenvolvimento de exportaçóes primárias favorece a expansão de novas atividades produtivas, como serviços produtivos, por duas dinâmicas: (i) a interação entre escalas de produção e tamanho dos mercados externos favorece a redução de custo das indústrias situadas hacia adelante, o que explica sobretudo a expansão das commodities industriais; e (ii) a atividade primário-exportadora incrementa a demanda de insumos fornecidos por indústrias e atividades situadas hacia atrás, e pode fazê-lo em escala econômica viável. Para Diaz (1996) este fenômeno tem sido menos importante do que o anterior, mas facilitou a expansão da produção de equipamentos e bens de capital, bem como o desenvolvimento de serviços de engenharia para a produção mineral, pesqueira e florestal.

Ainda assim, Moguillansky (1999, p. 293) observa que, "inclusive en las ramas que hacen uso intensivo de recursos naturales, como el sector forestal o el minero, no se han desarrollado eslabonamientos hacia atrás o hacia adelante para la fabricación de productos de mayor valor agregado”.

\section{O cobre}

Apesar de ter reduzido sua participação nas exportaçóes chilenas, o cobre ainda é bastante importante para a economia do país, sendo o Chile o maior produtor mundial. A Tabela 5 traz a participação chilena na produção mundial de cobre durante o século XX.

Podemos dizer que o cobre está muito ligado ao desenvolvimento do Chile no século XX, já que se trata da principal riqueza do país.

En el período previo a 1970, el cobre representaba cerca del 75\% de las exportaciones chilenas. En la primera mitad de la década del 50, la tributación al cobre constituía mas del 30\% de la recaudación fiscal; en el año 1955 dicho porcentaje casi llega al 50\%. En síntesis, el cobre generaba el $75 \%$ de las divisas y aportaba el 30\% de los ingresos tributarios. Durante gran parte del siglo XX, las divisas constituían el cuello de botella del desarrollo económico; en consecuencia, el cobre constituía el principal mecanismo para financiar la adquisición de maquinarias y tecnología moderna. Además, si Chile no hubiera tenido cobre, los contribuyentes chilenos habrían tenido que experimentar un aumento de impuestos de 
$30 \%$ para financiar un gasto público similar al que hubo (MELLER, 2003, p. 2).

Tabela 5 - Participação chilena na produção mundial de cobre durante o século XX

\begin{tabular}{|c|c|}
\hline Ano & Participaçáo na produçáo total mundial (\%) \\
\hline 1900 & 5,3 \\
\hline 1910 & 10,2 \\
\hline 1929 & 16,5 \\
\hline 1938 & 17,5 \\
\hline 1950 & 14,4 \\
\hline 1960 & 12,6 \\
\hline 1970 & 10,9 \\
\hline 1980 & 13,8 \\
\hline 1990 & 17,8 \\
\hline 2000 & 36,4 \\
\hline 2004 & 37,3 \\
\hline
\end{tabular}

FONTE: Para 1900 a 2000, World Bank (1987), World Bureau of Metal

Statistics apud MELLER, 2003, p. 4.; para 2004, Procobre, 2007

Durante os anos 1990 houve um aumento de empresas privadas na produção chilena de cobre, o que fez com que diminuísse a importância que a CODELCO tinha no passado, já que a mesma representava quase $85 \%$ da produção chilena de cobre em 1980; esta participação diminuiu a 33\% em 2000. O espetacular crescimento econômico da China nos últimos anos tem contribuído para o aumento da demanda pelo produto, levando a cotação da commodity a níveis recordes nos mercados internacionais, o que tem ajudado países produtores como Peru e Chile. Em 2006 o cobre atingiu seu valor mais alto (acima de USD 8.000,00 a tonelada) desde que começou a ser negociado no mercado financeiro em 1870.

Atualmente a China é o maior consumidor no mundo de cobre, sendo responsável por $22 \%$ da demanda mundial. A previsão é de que a demanda chinesa continue alta nos próximos anos, pois é esperada uma segunda onda de urbanização. A demanda deverá ampliar-se ainda pela necessidade de reconstruir as cidades devastadas pelos furacóes Katrina e Rita, nos Estados Unidos, e Stan, no México.

As atividades baseadas em recursos naturais podem ser relativamente 
intensivas em conhecimento. Inclusive um setor como a mineração pode tornar-se um fenômeno de aprendizagem coletivo. A experiência norteamericana é interessante, tendo em vista que no final do século XIX e começo do XX a economia dos EUA era relativamente intensiva em recursos naturais. Assim, para que um país se desenvolva a partir de seus recursos naturais, o que interessa não é o tipo de recurso natural que ele possui, mas sim o processo de aprendizagem que é gerado através da exploração desse recurso natural.

Meller (2003, p. 23) assinala três elementos que favoreceram o desenvolvimento com uso intensivo da dotação de recursos naturais nos EUA:

i) Un entorno legal acomodaticio y bastante liberal (siglo XIX); acceso abierto a la exploración, derechos de propiedad exclusivos para explotar un yacimiento descubierto, y el requerimiento de demostrar actividad productiva en el yacimiento para no perder el derecho de explotación. ii) Si bien ha habido en EEUU una rápida explotación hasta el agotamiento de muchos yacimientos de recursos naturales, la característica central de este proceso está fundamentalmente asociada al proceso continuo de aprendizaje, inversión, progreso tecnológico y reducción de costos generando de esta manera una notoria expansión mas que agotamiento de la dotación de recursos naturales del país. iii)El tercer elemento es la educación minera. EEUU se transformó en el país líder en ingeniería y metalúrgica. El desarrollo minero y petrolero constituyeron la base de una industria del conocimiento tecnológico. Ya a fines del siglo XIX, geólogos norteamericanos eran contratados como consultores en todo el mundo para prospección de petróleo y de yacimientos mineros. En realidad no es la geología (ni el capital financiero), sino que la inversión en conocimiento geológico lo que explica el dominio norteamericano en la producción mundial de petróleo. (MELLER, 2003, p. 23) 


\section{O setor florestal}

O crescimento das exportaçóes do setor florestal é interessante pois, apesar da abundância de recursos naturais existente no Chile neste setor, foi necessária uma política industrial para dar o grande impulso que a transformaria em uma indústria importante. A política industrial para este setor, que teve início em 1974, pode ser considerada como "o único caso que teve grande escala e grande êxito. Ela incluía incentivos especiais para o desenvolvimento do setor e um marco jurídico favorável à empresa privada e às exportaçôes, que eliminava as restriçôes de liquidez ao investimento e favorecia a acumulação de capital humano específico no setor." Além disso, entre 1975 e 1979, o Banco Central outorgou aos bancos comerciais e ao Banco del Estado uma linha de crédito especial para financiar projetos de desenvolvimento florestal, com condiçóes vantajosas para as empresas pequenas. (AGOSIN, 1999, p. 95) A exportação de produtos florestais correspondia a menos de $0,5 \%$ do total antes de 1973 e atingiu 7,9\% do total no início dos anos 1980 .

Há muito tempo sabia-se que o Chile tinha vantagens comparativas na silvicultura. As condiçôes do clima e do solo asseguram o crescimento rápido de certas espécies. Com base nesta dotação de recurso natural, durante os anos 1950 a Universidad de Chile e a Universidad Católica começaram a oferecer programas em engenharia florestal. Desta forma, quando o setor começou a desenvolver-se, a indústria já contava com um corpo significativo de especialistas. Quando as condições tornaram-se favoráveis, uma quantidade significativa destes profissionais transformaram-se em empresários (AGOSIN, 1999, p. 95).

\section{O vinho}

Outro produto cujo crescimento das exportações tem sido significativo é o vinho. Apesar de ser uma atividade tradicional no Chile, desde a época colonial, "os tipos de vinhos produzidos até meados dos anos 1980 não eram apreciados pelos consumidores dos países desenvolvidos. Era necessária

\footnotetext{
${ }^{7}$ En 1974 se instituyó un subsidio de 75\% del costo de plantación de árboles (Decreto Ley 701). Al mismo tiempo, la tierra privada plantada fue declarada inexpropiable, se derogó la prohibición de cortar árboles de menos de 18 años, y se autorizaron las exportaciones de madera sin elaborar. Estos cambios legales hicieron posible y muy provechosa la integración vertical [...] (AGOSIN, 1999, p. 95).
} 
uma mudança tecnológica em grande escala para que os vinhos chilenos pudessem ser vendidos no exterior." (AGOSIN, 1999, p. 96) e também um efeito demonstração. "Em 1981 a firma espanhola de Miguel Torres adquiriu terrenos grandes no vale central (Curicó) e começou a produzir vinhos com a nova tecnologia. O sucesso desta firma fez com que outras empresas adotassem a mesma estratégia." (AGOSIN, 1999, p. 96). Com a abertura econômica foi facilitada a importação de maquinários novos. Além disso, "em anos mais recentes investiram no Chile outras empresas grandes da Europa e Estados Unidos, como Rothschild, Larose Trintaudon, Grand Marnier, Roberto Mondavi y Christian Brothers)." Além disso, "vários vinhedos pequenos especializados estão fabricando produtos novos para o mercado de exportação e estão tentando vender seus vinhos a preços mais altos e com qualidade superior à das empresas tradicionais. Estes produtores, com menos capital que as empresas grandes, se apóiam nas associaçóes de novos produtores de vinhos para colocar seus produtos no exterior." (AGOSIN, 1999, p. 96). Em 2002 o vinho chileno já era exportado para mais de noventa países, de cinco continentes, superando a cifra de USD 600 milhóes. Em um par de décadas, surgiram no Chile enólogos de prestígio mundial.

Apesar destes êxitos inquestionáveis, a indústria vinícola chilena enfrenta agora o desafio de consolidar as conquistas do que se chama muitas vezes de "etapa fácil” do esforço exportador e conseguir

mejorar la imagen del producto y priorizar la calidad por sobre la venta de volumen. Así mismo, para lograr un mayor liderazgo deberá transformar una actitud reactiva, por una proactiva, es decir, que se antepone a los ciclos y los remonta con la innovación. (...) existen algunas señales de amenaza a su competitividad. En primer lugar, Australia, su principal competidor en el mundo, le ganó terreno en los principales mercados de exportación de vino, teniendo un marketing mucho más agresivo y orientado a los segmentos de mercado de mayor precio. El menor valor por litro exportado de Chile, se explica porque la industria vende más del $80 \%$ del vino embotellado en los segmentos de más bajo precio. De hecho, Chile ganó mercados vendiendo a los precios más bajos por igual o mejor calidad. También se explica por el alto porcentaje vendido a granel, el que fue aumentando entre el 2000 y el 2005, casi alcanzando el $45 \%$ 
del volumen total exportado. Chile también concentra las exportaciones de vinos embotellados en los segmentos de vinos corrientes y de mesa, en circunstancias que quedarse en los segmentos de bajo precio es un negocio arriesgado, por la extrema competencia en un mercado en que los analistas definen como de exceso de oferta y demanda decreciente. (MOGUILLANSKY, SALAS, CARES, 2006, p. 18).

\section{A transição do Chile para a orientação exportadora}

A abertura comercial e a desregulamentação do setor externo apareciam nas primeiras orientaçóes de política econômica da ditadura, da mesma forma que a orientação exportadora com apoio ativo do Estado. Na política econômica, contudo, somente depois da grave crise de 1981-82 a defesa das exportaçóes passou a ocupar lugar central, com a política de câmbio real estável e depreciado, em defesa da qual foram aplicados controle seletivos à entrada de capitais de curto prazo. Nesta mesma década, a abertura comercial multilateral e generalizada, com alíquota comercial baixa e comum para quase todos os produtos, foi acompanhada pela busca de acordos comerciais bilaterais com diferentes países e blocos econômicos. Ao longo de todo o período, foram mantidos e aperfeiçoados os instrumentos de intervenção estatal (incentivos, regulação, compras públicas), de grande relevo para a estratégia exportadora.

No final da década passada, os efeitos da crise asiática estimularam a reflexão sobre os limites dos êxitos alcançados:

Chile creció a tasas altas en los 90, siendo el sector exportador líder y motor del crecimiento. Esta evolución llevó a que en más de un producto - commodities basados en recursos naturales-, el país hoy lidere o esté entre los principales proveedores del mercado mundial. Esta constatación, lejos de llevar al país a la autocomplacencia, debiera conducirlo a impulsar un gran esfuerzo de innovación, en los productos, procesos y modelos de negocios de las industrias que hoy son líderes. Cabe destacar que países especializados en el procesamiento de recursos naturales, como los casos de Australia y Nueva Zelanda, han podido acceder a nuevos 
mercados, copar nuevos nichos y superar la dependencia de los precios de los commodities, en base a la creación permanente de nuevos productos, comercialización de nuevos servicios y procesos (MOGUILLANSKY, SALAS, CARES, 2006, p. 7).

Esta seção está dividida em três partes: a primeira resume a política econômica ao longo destes trinta anos, a segunda apresenta e discute o papel decisivo do Estado no sucesso da orientação exportadora e a última apresenta elementos para a discussão das mudanças no setor produtivo chileno induzidas pela ênfase nas exportaçôes.

\section{A política econômica}

Do ponto de vista da orientação para exportaçóes, podemos dividir as décadas recentes em três períodos principais: i) implantação das reformas logo após o golpe militar de 1973; ii) da crise de 1981 até a recuperação, na segunda metade dos anos 1980, com recuos em algumas políticas liberalizantes e importante reorientação da política econômica, em especial no câmbio; iii) a partir dos últimos anos da década de 1980, quando se consolidou a orientação exportadora, com ampliação da abertura comercial e diversos acordos comerciais com blocos e países. Esta periodização não coincide com o desempenho macroeconômico do período mais relevante para a definição do modelo exportador (ver dados de 1974 a 1996 na Tabela 6), que mostra fortes oscilaçóes nos principais indicadores até meados dos anos 1980 . 
Tabela 6 - Chile: indicadores macroeconômicos, médias anuais de períodos selecionados, 1974-1996

\section{\begin{tabular}{l|l|l|l|l|l|l|l|}
$74-75$ & $76-79$ & $80-81$ & $82-83$ & $84-85$ & $86-89$ & $90-93$ & $94-96$
\end{tabular}}

1. Atividade econômica

Crescimento do PNB

\begin{tabular}{l|l|l|l|l|l|l|l|}
-6.2 & 7.4 & 6.7 & -7.6 & 4.4 & 7.3 & 6.9 & 6.6
\end{tabular}

Investimento/PNB*

\begin{tabular}{l|l|l|l|l|l|l|l}
15.4 & 15.6 & 19.5 & 12.9 & 14.8 & 23.5 & 26.5 & 27.2
\end{tabular}

Taxa de desemprego*

\begin{tabular}{|l|l|l|l|l|l|l|l|}
13.5 & 13.8 & 10.9 & 18.6 & 12.2 & 5.3 & 5.9 & 5.7 \\
\hline
\end{tabular}

\begin{tabular}{|l|c|c|c|c|c|c|c|c|}
\hline 2. Preços domésticos & 358 & 69 & 20 & 22 & 25 & 18 & 18.0 & 8.7 \\
\hline Inflação & -4.1 & 14.3 & 8.8 & -5.5 & -2.1 & 2.6 & 3.9 & 5.1 \\
\hline Variaçáo salário real & 83.0 & 1.4 & -13.2 & 15.7 & 13.3 & 4.5 & -2.8 & -3.7 \\
\hline Variaçáo taxa de câmbio real. & 15.9 & 43.9 & 24.8 & 25.1 & 11.1 & 8.9 & 11.1 & 9.9 \\
\hline Taxas de juros real & &
\end{tabular}

\section{Setor externo}

Termos de variação no comércio

\begin{tabular}{l|l|l|l|l|l|l|l|}
-33.1 & 2.6 & -3.5 & -3.6 & -5.4 & 7.3 & -3.6 & 1.6 \\
\hline
\end{tabular}

\begin{tabular}{|l|l|l|l|l|l|l|l|l|} 
Variação do volume exportação & 22.2 & 15.3 & 2.0 & 2.7 & 6.8 & 11.1 & 9.5 & 9.3
\end{tabular}

Balança comercial/PNB*

\begin{tabular}{l|l|l|l|l|l|l|l|}
-2.0 & -2.8 & -10.3 & 2.7 & 2.8 & 4.5 & -2.3 & 8.6
\end{tabular}

Conta corrente/PNB*

\begin{tabular}{l|l|l|l|l|l|l|l|}
-5.2 & -5.4 & -14.5 & -5.4 & -8.3 & -1.8 & -4.8 & 0.1
\end{tabular}

Dívida externa/ Exportações*

\begin{tabular}{l|l|l|l|}
3.1 & 1.6 & 3.1 & 4.0
\end{tabular}

$\begin{array}{llll}4.6 & 1.7 & 1.6 & 1.1\end{array}$

\section{Políticas macroeconômicas}

\begin{tabular}{|l|c|c|c|c|c|c|c|c|}
\hline Superávit fiscal/PNB* & 2.1 & 5.2 & 3.3 & -1.2 & -0.2 & 5.0 & 0.8 & 1.3 \\
\hline Crescimento do M1 & 260 & 112 & 31 & 6 & 23 & 37 & 28 & 19.7 \\
\hline Taxa de câmbio nominal & 390 & 47 & - & 49 & 45 & 13 & 5 & -0.8 \\
\hline
\end{tabular}

* Referem-se aos valores correspondentes ao último ano do período.

Nota: Crescimento do PNB: refere-se à variação da média do PNB anual, medido a preços constantes de 1977 para o período 1976-85, e a preços constantes de 1986 para o período 1986-96.

FONTE: Banco Central de Chile, Instituto Nacional de Estatística (INE), Edwards ${ }^{8}$ (1984), Fontaine9 (1996, table 1) apud EDWARDS e LEDERMAN, 1998, p.58.

\footnotetext{
${ }^{8}$ Edwards, Sebastian. 1984. The Order of Liberalization of the External Sector in Developing Countries. Princenton Essays in International Finance 156. Princenton University, Princenton, NJ.

${ }^{9}$ Fontaine, Juan Andrés. 1996. La construcción de un mercado de capitales: El caso de Chile. Washington, DC: The World Bank.
} 
Nos primeiros anos após o golpe militar de setembro de 1973, a economia chilena passou por profundas e drásticas mudanças estruturais, entre elas as aberturas comercial e financeira. Foram eliminadas quase todas as restriçóes comerciais (FFRENCH-DAVIS, 2002a) e o imposto de importação foi fortemente reduzido (Tabela 7). A política comercial era muito complexa até então:

Había 57 tasas arancelarias distintas, que iban desde cero a 220\% (más sobretasas en varios artículos), muchas medidas no arancelarias (depósitos previos de importación, prohibiciones, contingentes, etc.) y un sistema de tipos de cambios múltiples con ocho precios para el dólar, el mayor de los cuales era 10 veces más alto que el más bajo. Este particular sistema de protección no respondía a ningún objetivo de desarrollo. (AGOSIN, 1999, p. 88)

Tabela 7 - Chile: alíquota de importação média (\%) e taxa real de câmbio (1986=100), 1973-2001

\begin{tabular}{|c|c|c|}
\hline Ano & Alíquota de importaçáo média (\%) & Taxa real de câmbio $(\mathbf{1 9 8 6}=\mathbf{1 0 0})$ \\
\hline $\mathbf{1 9 7 3}$ & 94,0 & 65,1 \\
\hline $\mathbf{1 9 7 4 - 7 9}$ & 35,3 & 73,2 \\
\hline $\mathbf{1 9 8 0 - 8 2}$ & 10,1 & 57,6 \\
\hline $\mathbf{1 9 8 3 - 8 5}$ & 22,7 & 79,1 \\
\hline $\mathbf{1 9 8 6 - 8 9}$ & 17,6 & 106,6 \\
\hline $\mathbf{1 9 9 0 - 9 5}$ & 12,0 & 99,5 \\
\hline $\mathbf{1 9 9 6 - 9 8}$ & 11,0 & 80,3 \\
\hline $\mathbf{1 9 9 9 - 2 0 0 1}$ & 9,0 & 88,4 \\
\hline
\end{tabular}

FONTE: Banco Central de Chile apud FFRENCH-DAVIS, 2002a, p. 145.

Havia uma intenção deliberada de acabar com o modelo de substituição de importaçóes ${ }^{10}$, embora sem percepçáo clara quanto ao ritmo e às condiçóes

\footnotetext{
10 "Entre muchas otras declaraciones que reiteran la orientación hacia afuera de las políticas económicas del gobierno Pinochet puede citarse las palabras de su ministro de Economía en una conferencia de prensa dada en febrero de 1985: 'El crecimiento hacia afuera - movido por las actividades con capacidad de enfrentar ventajosamente los rigores de la competencia internacional - es un sello distintivo de la estrategia sustentada por el Supremo Gobierno ... El propósito es operar una profunda reconversión de nuestro sistema productivo, estimulando preferentemente las actividades conectadas a la exportación y, en general, a las productoras de bienes transables" BCCH, Boletín Mensual No. 684, febrero de 1985 apud GLAUSER, 1989, p. 157
} 
em que devia ser implantada a nova política. ${ }^{11}$ A posição inicial de que o câmbio deveria ser desvalorizado para incentivar as exportaçóes e favorecer o balanço de pagamentos levou a uma desvalorização forte em outubro de 1973 e seguiu-se um sistema de míni-desvalorizações (crawling peg) até janeiro de 1978, com duas pequenas valorizaçóes em junho de 1976 e em março de 1977. Vale observar que a redução das alíquotas aumentou o nível de proteção efetiva à agricultura, pois antes o controle de preços agrícolas e a economia relativamente fechada que encareciam os insumos importados (EDWARDS, LEDERMAN, 1998). Esta situação ocorria também em outros setores em que as empresas dependiam de insumos importados.

A política cambial foi alterada em 1978. Com a orientação de ajuste monetário do balanço de pagamentos, a taxa de câmbio tornou-se a principal âncora contra a inflação. A taxa de desvalorização foi prefixada para um ano e em 1979 o peso foi atrelado ao dólar, o que provocou forte valorização do câmbio real até 1982 (EDWARDS, LEDERMAN, 1998).

Em trabalho sobre comércio exterior e crescimento no Chile, Agosin (1999) destaca que na área financeira, as reformas iniciadas em 1975 incluíram privatização de bancos, com redução das restriçôes à entrada no setor financeiro, ao lado de corte das taxas de encaixe bancário e eliminação de tetos máximos para os juros. Sem regulaçôes prudenciais, o setor financeiro cresceu enormemente e as taxas de juros passaram de muito negativas a muito altas em termos reais.

A combinação entre abertura econômica abrupta e apreciação do peso levou à grave crise financeira e cambial de 1981, agravada pela crise da dívida externa em toda a América Latina em 1982, com a moratória mexicana. Com a desvalorização do peso e a quebra de muitos bancos e empresas, o PIB caiu 14\% em 1982 e o desemprego atingiu 18,6\% em 1983.

A crise induziu a revisão da ortodoxia neoliberal e a adoção de políticas pragmáticas. A geração de saldos comerciais positivos passou a ser um dos objetivos principais, para atender ao serviço da dívida externa. As medidas

\footnotetext{
11 "Initially, however, the authorities had no precise idea about how deep and how fast the liberalization should be. In fact, only after Chile withdrew from the Andean Pact in December of 1977, did the chief of economic strategist, Minister Sergio de Castro, announced that the final goal was to reduce tariffs to a uniform rate of 10 percent by mid-1979. In explaining this change in tariff policy, de Castro pointed out that the prevailing differentiated tariff structure of rates between 10 percent and 35 percent generated an unjustifiable discriminatory situation”. (EDWARDS, LEDERMAN, 1998, p. 4).
} 
adotadas incluíram desvalorização do câmbio, incentivos às exportações (MOGUILLANSKY, 1999), flexibilização da política comercial, com aumento das alíquotas de importação para 35\%, medidas antidumping, bandas de preços similares aos internacionais para os três produtos agrícolas principais (trigo, açúcar e oleaginosas), aperfeiçoamento do drawback, e outras (FFRENCH-DAVIS, 2002a, 2002b).

$\mathrm{O}$ ajuste na conta corrente foi rápido e as tarifas de importação foram reduzidas para 20\% em junho de 1985 e para 15\% em maio de 1988 . (EDWARDS, LEDERMAN, 1998). O aumento inicial da alíquota de importação serviu para encorajar a produção interna de alguns produtos para competir com importados (FFRENCH-DAVIS, 2002b) e a redução posterior ajudou a conter a inflaçãa ${ }^{12}$ com a forte recuperação econômica, estimulada pelos juros reais moderados em termos reais, "favorecendo o investimento e a aquisição de tecnologia.” (AGOSIN, 1999, p. 90).

A mudança na política cambial teve papel decisivo, com a ênfase em taxa de câmbio real depreciada para favorecer as exportaçóes:

Entre otras medidas, mediante la fijación de un tipo de cambio real elevado que mejoró apreciablemente la rentabilidad de la producción de bienes transables. En 1985, el tipo de cambio real subió un 25\% por encima del ya elevado nivel que había alcanzado en 1984, volvió a subir un 13\% en 1987 y se mantuvo en los tres ańos siguientes. Como consecuencia, en 1989 el tipo de cambio real era 1,9 veces el vigente al producirse el colapso de 1981-82. En este contexto, la proporción exportada del producto pasó de $23,7 \%$ en 1980 a 28,9\% en 1989. (DAMILL, FANELLI, FRENKEL,1994, p. 210).

O sistema de câmbio adotado após 1983 foi novamente o crawling peg:

Fundamentalmente, el Banco Central fijaba en el mercado oficial un precio de referencia para el dólar (llamada tipo de cambio acuerdo, TCA), con una banda de flotación inicialmente pequeña, que fue ampliándose

12 Em seu paper, Gregorio (2004), analisa o papel que o crescimento da produtividade teve na desinflação do Chile nos anos 1990. Ele conclui que o papel foi fundamental no combate à inflação e que o crescimento sustentável do Chile é resultado de boas políticas econômicas, assim como boas instituições. 
cada cierto tiempo. El tipo de cambio "oficial" se devaluaba diariamente, de acuerdo con el diferencial entre la inflación interna y una estimación de la inflación externa. A ello se sumaron, en varias ocasiones, devaluaciones discretas, las que permitieron la notable depreciación real que se registró después de la crisis de 1982 (130\% entre 1982 y 1988). (FFRENCHDAVIS, 2002a, p. 147)

O governo não se limitou ao manejo dos instrumentos macroeconômicos tradicionais e adotou uma série de medidas de incentivo direto às exportaçóes. A isenção de IVA exigia a emissão de muitos documentos e tinha custo financeiro para a empresa, que devia pagar o imposto para depois recuperálo. Na devolução simplificada, nas exportaçóes de menos de 20 milhóes de dólares todos os exportadores recebem um subsídio de 3\%, 5\% ou $10 \%$ sobre o valor da exportação, processo mais simples para exportadores pequenos e médios. ${ }^{13}$ Em 1994 o Estado pagou US\$ 150 milhóes como devolução simplificada e apenas US\$ 26 milhóes de dólares por isenção do IVA (AGOSIN, 1999).

O Estado também contribuiu para o estímulo às exportações não minerais, por meio das "Políticas de inversión extranjera directa", um "programa de conversão da dívida em capital cujos objetivos eram diminuir a carga da dívida externa e, ao mesmo tempo, fomentar o investimento estrangeiro direto" (AGOSIN, 1999, p. 94) e que vigorou de 1985 a 1991. Para Ffrench-Davis (1990), o programa não tinha a neutralidade e o automatismo do regime de investimento estrangeiro direto e oferecia forte subsídio ao investimento estrangeiro direto: "Assim, as autoridades fizeram da necessidade uma virtude e impulsionaram uma política industrial com outro rótulo. [...] Por volta de $40 \%$ de todo o investimento direto estrangeiro durante o período mencionado acima foi realizado com conversão de dívida em capital”.

A equipe econômica que assumiu em 1990 manteve os princípios básicos da política comercial anterior. As tarifas de importação ficaram inalteradas até 1999 (média de 11\%), sendo reduzidas progressivamente até atingirem

\footnotetext{
${ }^{13}$ Agosin (1999, p. 93) afirma: "Aunque no ha habido estudios econométricos cuidadosos del impacto del reintegro simplificado en la aparición de nuevas exportaciones, no puede ser coincidencia que después de la introducción del sistema el número de productos manufactureros exportados, y sus valores, crecieran rápidamente.”
} 
6\% em 2003. (FFRENCH-DAVIS, 2002a). ${ }^{14}$ A novidade principal foram os acordos comerciais com diversos países: no âmbito da ALADI, acordos de complementação econômica com Bolívia, Colômbia, Equador, Peru, Venezuela e com o Mercosul; acordos de livre comércio com Associaçáo Européia de Livre Comércio, Mercado Comum Centro-Americano, Canadá, Coréia do Sul, União Européia e EUA (LOPES, CARVALHO, 2007).

Na política cambial, na maior parte dos anos 1990 o sistema foi o crawling peg com bandas, mas com intervençóes notavelmente mais ativas. Do mesmo modo que outros países da América Latina, o câmbio tendeu a valorizarse, principalmente durante a primeira metade da década, devido ao grande ingresso de capital externo e foram adotadas diversas medidas a fim de evitar uma apreciação excessiva:

En Chile se introdujeron significativos ajustes en la política cambiaria, para resistir la tendencia a la apreciación; así, el tipo de cambio, que estaba ligado sólo al dólar estadounidense, paso a depender de la trayectoria de una canasta de monedas, a fin de desalentar los flujos de capital especulativos que operaban predominantemente en dólares, y el Banco Central se involucró activamente en el mercado cambiario, incluyendo la intervención intramarginal (dentro de la banda). Además, se instauraron impuestos y requisitos de encaje a los créditos externos y depósitos en moneda extranjera, para encarecer su costo en el mercado interno con miras a morigerar la oferta de divisas ante la oleada de capital externo y reducir la significación de los flujos de corto plazo. (FFRENCH-DAVIS, 2002a, p. 151) $)^{15}$

Entretanto, essas medidas foram perdendo sua eficácia na segunda metade

\footnotetext{
${ }^{14}$ Ello ha conllevado la eliminación de la regla simple consistente en aplicar un arancel uniforme a todas las importaciones incorporando una discriminación para un mismo tipo de bien según su país de origen. Se establecieron además categorías específicas de bienes con reducción arancelaria rápida, lenta, o mediana, y productos excluidos que constituyen excepciones para las preferencias. Estas medidas afectaron la competitividad de algunos sectores, pero también estimularon el incremento en la productividad (MOGUILLANSKY, 1999, p. 54).

${ }^{15}$ Gregorio, Edwards e Valdés (2000), analisam a eficácia do controle de capital na economia chilena, examinando os efeitos na taxa de juros, na taxa de câmbio real e no volume e composição do fluxo de capital. Eles concluem que a evidência econométrica não mostra efeitos significativos no diferencial da taxa de juros no longo prazo, nem na taxa de câmbio real. Mas, houve uma mudança na composição do fluxo de capital em direção à uma maturação mais longa.
} 
da década. Como conseqüência, entre 1995 e outubro de 1997, houve uma apreciação real de 16\%, contribuindo para a elevação do déficit externo, que atingiu 5,7\% do PIB no biênio 1996-1997. Com o advento da crise asiática, houve fuga de capitais, forçando a desvalorização, que foi evitada através do aumento de juros e do estreitamento da banda cambial. Finalmente, em setembro de 1999, o Banco Central decidiu deixar o câmbio flutuar ${ }^{16}$.

\section{O papel do Estado}

O Estado teve participação ativa no direcionamento da economia nas últimas décadas e fez uso de diversas políticas e instrumentos de apoio a atividades intensivas em recursos naturais e ao setor exportador. As políticas se iniciaram com a criação de mecanismos de ajuda aos devedores e aos bancos, para logo prosseguir com a reprivatização de empresas e do sistema financeiro, a correção dos preços relativos, geração de incentivos ao investimento estrangeiro, facilitação ao acesso dos investidores institucionais ao mercado de capitais e, finalmente, a promoção e o estímulo do setor exportador (MOGUILLANSKY, 1999). O Estado regulou de maneira efetiva a evolução dos mercados estratégicos (juros, câmbio, salário mínimo, bandas de preços agrícolas e tarifas públicas), visando provocar uma modificação estrutural dos preços relativos, a fim de criar um ambiente mais favorável para as empresas exportadoras (DIAZ, 1996, p. 275). Acrescente-se que a reforma tributária de 1984 foi orientada para estimular o investimento (ver MARFÁN, 1984; CARVALHO, 1997).

Papel destacado coube à Codelco, a maior produtora de cobre do país e que permaneceu em poder do Estado. Além de importante fonte de divisas para o setor público, a Codelco operou como instrumento de política industrial com a "política de compras de insumos y bienes de capital a empresas nacionales, lo que favoreció la retomada del crecimiento del sector metal-mecánico" (DIAZ, 1996, p. 275).

Os principais investimentos foram efetuados em atividades chaves, como: i) as vinculadas aos setores dinâmicos das exportaçóes: mineração e indústria (agroindústria, derivados da pesca e florestal); e ii) os setores de

16 Para uma análise do contexto econômico e do processo de adoção do regime de flutuação cambial com metas de inflação no Chile, ver Russo (2004) e Cunha (2006). 
infraestrutura: energia, telecomunicaçóes, infraestrutura viária, portuária e sanitária, que representam áreas fundamentais para o desenvolvimento da competitividade internacional.

Os beneficiados pelos incentivos do governo, foram

[...] en primer lugar, los que hoy se han transformado en los grandes grupos económicos, generando las condiciones y recursos básicos de la expansión. En segundo lugar, el capital extranjero, que tuvo una participación importante como coadyuvante, pero no como protagonista en este proceso. Los beneficios de la política de este período no se limitaron a estos agentes, sino que también alcanzaron a las grandes y medianas empresas, que pudieron desarrollarse en los espacios y actividades abiertas por los conglomerados, mientras que las pequeñas empresas [...] quedaron marginadas del proceso. (MOGUILLANSKY, 1999, p. 61)

Coube papel destacado ao ProChile, órgão de promoção de exportações subordinado à Dirección General de Relaciones Econômicas Internacionales - Direcon, do Ministério das Relaçóes Exteriores. Criado em 1974, no contexto de mudança brusca para a abertura externa e ênfase nas exportaçóes, o ProChile recebeu a missão de:

Perform studies and develop methods to guide and train entrepreneurs in - Using new information technologies - Organizing international trade fairs and business missions - Developing programs to help SMEs enter the global marketplace - Conducting national calls for proposals for export promotion programs [...] Among many other services, this network provides market data and makes it easier to establish business contacts. (PROCHILE, 2003)

O ProChile teve grande papel no aumento das exportações desde então e conta hoje com 13 escritórios no Chile e agências em 56 países. ${ }^{17}$ Os

\footnotetext{
${ }^{17}$ Vale observar que órgãos de promoção das exportações são tão importantes que em alguns países, como os Estados Unidos, eles não estão limitados à esfera federal, tendo atuação também estadual: "All 50 U.S. states have offices to assist firms in selling goods and services abroad and the resources devoted to export promotion by states rose from USD 21 million to USD 96 million from 1984 to 1992" (BERNARD, JENSEN, 2001, p. 2).
} 
escritórios no Chile têm a função de fornecer orientação e informação relevante e atualizada sobre os mercados internacionais. Além disso, proporciona assistência técnica e estratégica para a preparação e execução de Programas de Promoción de Exportaciones, e outras açóes para o intercâmbio comercial.

O ProChile conta com a assessoria de especialistas em quatro áreas: i) departamento de alimentos; ii) departamento de indústrias; iii) departamento de serviços; e iv) departamento regional e pequenas e médias empresas. Como exemplo, os serviços prestados pelo departamento de alimentos engloba: i) informação sobre os instrumentos e ferramentas que oferece o ProChile; ii) apoio e orientação no processo exportador; iii) entrega de informação setorial; iv) guia para o desenho de estratégias de promoção de exportaçóes e coordenação de agendas de reuniōes no exterior; v) assistência na formulação de programas de promoção de exportaçóes tanto para o Concurso Público como no Concurso para Internacionalización de la Pequeña Agricultura Campesina, bem como entrega de informação sobre a forma de operar dos mesmos; vi) guiar as pequenas e médias empresas para que possam ter acesso ao instrumento de internacionalização da pequena e média empresas; e vii) organização de programas institucionais de interesse estratégico setorial (com associaçôes gremiais). O Prochile também contribui para a criação de reputação dos produtores locais no exterior, a chamada "criação da imagem do país no exterior", através de meios de massa de comunicação nos mercados objetivos. Trata-se de propagar a marca "Chile" nos produtos exportados. Isso vai criando no exterior credibilidade para os produtos chilenos.

As empresas beneficiadas pelo ProChile exportavam mais, em valor médio e em número de produtos, e as empresas que exportavam a um número maior de mercados tinham uma probabilidade maior de usar os instrumentos do ProChile, o que demonstraria que estes instrumentos seriam utilizados por empresas com um grau maior de experiência exportadora. Por outro lado, empresas que estáo localizadas na capital têm uma probabilidade mais baixa de participar, o que pode ser consistente com os esforços do ProChile em incorporar empresas de regióes aos mercados internacionais, ou pela própria natureza das vantagens comparativas do Chile, que é um país relativamente abundante em recursos naturais, os quais não estáo localizados na capital. (ALVAREZ, CRESPI, 2000) 
Durante o decênio de 1990, as atividades de promoção comercial patrocinadas pelo Estado foram intensificadas. Grupos de empresas foram estimulados a formarem associaçóes, visando promover seus produtos e realizar em conjunto atividades que buscam um melhor conhecimento do mercado. O financiamento das atividades no exterior e os custos de administraçáo destes "Comités de Exportación" são subvencionados em escala decrescente por um período máximo de seis anos (AGOSIN, 1999).

Ffrench-Davis (2002b) destaca a importância da Fundación Chile, instituição semipública voltada para assistência técnica a alguns projetos. A idéia era determinar quais atividades poderiam se beneficiar de novas tecnologias. Como qualquer empreendimento de capital de risco, esta Fundação registrou muitos fracassos, mas também muitos casos de sucesso, como o cultivo de salmóes (AGOSIN, 1999). A partir de um projeto piloto de 1981 para o cultivo de salmôes em jaulas, em água doce (tecnologia desenvolvida na Noruega e Suécia), houve a primeira produção comercial em 1986-1987, duplicando no período seguinte. No ano de 1988 o ciclo se completou, quando o projeto começou a gerar lucros e a Fundação vendeu o projeto a uma companhia japonesa ${ }^{18}$ de pescados e mariscos comestíveis. Nos anos 1990 a exportação de salmão se tornou uma das mais importantes (CEPAL, 1998).

Las exportaciones de salmón de cultivo eran insignificantes en 1986, y llegaron a unos 700 millones de dólares en 1998. Chile abastece hoy cerca del 15\% del mercado mundial de salmones y truchas cultivados y es actualmente el segundo exportador del mundo detrás de Noruega. La industria de salmón constituye una verdadera historia de éxito en la cual la adaptación y el desarrollo tecnológicos desempeñaron un papel dominante. (AGOSIN, 1999, p. 95)

\section{Transformações no setor produtivo}

A abertura comercial faz com que as empresas passem por profundas transformaçôes e modifiquem comportamentos para sobreviver. No Chile,

\footnotetext{
${ }^{18}$ Trata-se da Nippon Suisan, empresa japonesa que é uma das maiores empresas pesqueiras do mundo.
} 
com a abertura econômica abrupta, a maioria das empresas passou por muitas dificuldades de adaptação. ${ }^{19}$

En el curso de los años 1973-87 la estructura productiva y el empleo manufacturero sufren modificaciones de importancia una vez que las bases sobre las que se construye la "nueva economía" ponen en pocos años en un lugar secundario el sector industrial, bajándolo de su pedestal de principal motor del desarrollo económico chileno. (GARCÍA, 1989, p. 102)

O empresariado chileno dos anos 1990 é bastante diferente do existente até a década de 1970. De acordo com Castillo e Alvarez ${ }^{20}$ (1998 apud MOGUILLANSKY, 1999) a concorrência desencadeada com a abertura dos mercados levou a maioria das empresas a empreender aceleradas mudanças em três âmbitos decisivos: i) estilos de gestão: tendência à profissionalização dos grupos diretivos e gerenciais; ii) estrutura da organização: simplificação, maior flexibilidade da administração, descentralização e criação de centros de custos; e iii) o desenvolvimento de estratégias comerciais.

[...] ha surgido un empresariado industrial renovado, definiéndolo a partir de las siguientes características: una trayectoria más profesional que patrimonial; un espíritu empresarial más dinámico y menos rentista; una identidad social autónoma y cosmopolita; una concepción más pragmática y menos paternalista de la empresa y

\footnotetext{
${ }^{19}$ Nos anos 80, aproximadamente 7.000 empresas fecharam suas portas no Chile (BENEVANTE, 1997).

"Entre 1974 y 1987 el crecimiento manufacturero tuvo un dinamismo que lo diferencia notablemente del resto de las actividades al ser uno de los sectores más afectados por la nueva política económica, mostrando un crecimiento promedio anual de apenas 0,6\%; bajando su participación en el PGB desde 27,5\% en 1973, a 21,2\% en 1987, es decir, una participación casi igual a la que se daba a fines de la década de los años cincuenta, pero con efectos graves en el empleo, la capacidad empresarial, tecnológica y productiva, en la propiedad y en las inversiones (GARCÍA, 1989, p. 110). Um fato interessante é que, no período de 1978-1983 houve muitas quebras, que afetaram principalmente as empresas que, ao invés de adotarem estratégicas defensivas, realizaram investimentos importantes em modernização tecnológica, basicamente mediante aquisição de máquinas e equipamentos no exterior, não podendo honrar suas dívidas ao mudar a política cambial e agravar-se o quadro recessivo. (CASTILLO, DINI, MAGGI, 1996).

${ }^{20}$ Castillo, Mario y Raúl Alvarez (1998). "El liderazgo en las grandes empresas en Chile", Grandes empresas y grupos industriales latinoamericanos: expansión y desafios en la era de la apertura y la globalización, Wilson Peres (coord.), México, D.F. Siglo Veintiuno Editores.
} 
de las relaciones laborales y una racionalidad económica expansiva. Esta imagen ciertamente contrasta con la expresión predominante del empresariado chileno, en relación con la empresa, que sigue reflejando una postura extremadamente ideologizada, propensa al rentismo, a la manutención de relaciones laborales atrasadas y a una visión global extremadamente provinciana. (MONTERO ${ }^{21}$, 1997 apud MOGUILLANSKY, 1999, p. 76)

O investimento estrangeiro direto (IED) no Chile passou de $1 \%$ do PIB em meados dos anos 1980 para 8\% no final dos anos 1990, com forte concentração em produtos químicos e produtos metálicos e presença muito baixa nos setores têxteis, vestuário, calçado, madeira e móveis (ALVAREZ, 2002, p. 5). Este aumento foi impulsionado pelo programa de conversão de dívida externa iniciado na metade dos anos 1980:

La inversión extranjera directa no aumentó hasta 1987, pero desde entonces su crecimiento ha sido ininterrumpido. Cerca de 60\% de todas las nuevas inversiones a través del régimen regular han ido al sector minero, en el cual Chile tiene claras ventajas comparativas. Otras políticas de inversión extranjera directa han tenido como resultado el estímulo de exportaciones no mineras. En 1985, las autoridades instituyeron un programa de conversión de deuda en capital cuyos objetivos eran disminuir la carga de la deuda externa y al mismo tiempo fomentar la inversión extranjera directa. Pero este canal para invertir en Chile no tenía la neutralidad y el automatismo del régimen de inversión extranjera directa. (...) el programa de conversión de deuda implicó un fuerte subsidio a la inversión extranjera directa (...); sin embargo, los proyectos tenían que ser aprobados caso por caso, con prioridad para las nuevas exportaciones. Así, las autoridades hicieron de la necesidad una virtud e impulsaron una política industrial con otro rótulo. Durante los años en que estuvo en operación (1985-1991), cerca de 60\% de las inversiones efectuadas en virtud de este programa tuvieron por destino las manufacturas y la agricultura, en su mayoría en los sectores forestal

${ }^{21}$ Montero, Cecilia (1997), La revolución empresarial chilena, Santiago de Chile, Corporación de Investigaciones Económicas para Latinoamérica (CIEPLAN), Editorial Dolmen. 
y de papel y celulosa. Alrededor del $40 \%$ de toda la inversión extranjera directa durante este período fue realizada con conversión de deuda en capital. (AGOSÍN, 1999, p. 93-94)

O Quadro 1 apresenta uma periodização do investimento privado no Chile de 1974 a 1988, período em que se desenvolveu e consolidou a atual estrutura produtiva ${ }^{22}$ :

Diversos grupos econômicos, no final dos anos 1990, foram obrigados a se concentrar. Neste ponto tiveram grande importância as vantagens comparativas. Podemos dizer que atualmente a indústria chilena é muito mais madura do que há algumas décadas atrás. Além de competir em um ambiente bastante distinto, ela é mais ativa, próspera e exportadora. Essa indústria também é hoje uma importante usuária de serviços de manutenção e consertos, atividades de transporte, comunicação, serviços financeiros, comercialização, etc., contribuindo para aumentar a "complexidade" da economia. É sabido, entretanto, que alguns setores perderam participação (particularmente têxtil e metal mecânico) e outros ganharam (indústria vinculada com o processamento de recursos naturais):

No es casualidad entonces que los estudios sectoriales de la época [1973-1983] hablaran correctamente de la desindustrialización, aunque el concepto a veces sobrepasó el limite preciso que debería tener destrucción de experiencia y desmantelamiento de capacidad industrial - confundiéndose incorrectamente con fenómenos de caída del producto y del empleo (DIAZ, 1996, p. 273).

22 Castilho, Dini e Maggi (1996), estudam, a partir de evidências empíricas, as novas estratégias competitivas que foram surgindo a partir dos anos 1980. Foram estudadas estratégias competitivas de 20 empresas, ilustrativas do universo de médias e grandes empresas. 
Quadro 1 - Sínteses das fases do investimento privado no Chile no período 1974-1998

\begin{tabular}{|c|c|c|}
\hline Período & Características do período & Respostas dos agentes \\
\hline $\begin{array}{l}\text { Fase I } \\
1974-85 \\
\text { a) } 1974-81 \\
\text { b) } 1982-85\end{array}$ & $\begin{array}{l}\text { - Estabilização } \\
\text { - Reforma Estrutural } \\
\text { - Privatizaçóes } \\
\text { - Crise dívida externa } \\
\text { - Política de ajuste } \\
\text { - Quebras de empresas privatizadas }\end{array}$ & $\begin{array}{l}\text { - Racionalização da gestão } \\
\text { - Redução de custos } \\
\text { - Reorientação de ativos } \\
\text { - Desarticulação grupos } \\
\text { econômicos } \\
\text { - Queda no investimento }\end{array}$ \\
\hline $\begin{array}{l}\text { Fase II } \\
1986-89\end{array}$ & $\begin{array}{l}\text { - Reativação } \\
\text { - Fortes incentivos estatais aos } \\
\text { conglomerados } \\
\text { - Orientação Externa } \\
\text { - Nova fase de reformas } \\
\text { - Re-privatizaçóes } \\
\text { - Regulação sistema financeiro }\end{array}$ & $\begin{array}{l}\text { - Reestruturação grupos } \\
\text { econômicos } \\
\text { - Ingresso de capitais } \\
\text { estrangeiros com reconversão } \\
\text { da dívida } \\
\text { - Orientaçáo exportadora } \\
\text { - Modernizaçáo tecnológica } \\
\text { - Forte aumento no } \\
\text { investimento }\end{array}$ \\
\hline $\begin{array}{l}\text { Fase III } \\
1990-95\end{array}$ & $\begin{array}{l}\text { - Consolidação no crescimento } \\
\text { - Estabilidade macroeconômica } \\
\text { - Diminuição incentivos públicos } \\
\text { - Re-valorização cambiaria moderada }\end{array}$ & $\begin{array}{l}\text { - Investimento externo direto } \\
\text { - Modernização tecnológica } \\
\text { - Expansão de plantas } \\
\text { - Internacionalização da } \\
\text { produção } \\
\text { - Forte dinamismo do } \\
\text { investimento em setores } \\
\text { processadores recursos } \\
\text { naturais, infra-estrutura e } \\
\text { construçãa. }\end{array}$ \\
\hline $\begin{array}{l}\text { Fase IV } \\
1996-98\end{array}$ & $\begin{array}{l}\text { - Estabilidade macroeconômica } \\
\text { - Diminuição incentivos públicos } \\
\text { - Melhor regulação serviços básicos } \\
\text { privatizados } \\
\text { - Re-valorização cambiaria } \\
\text { significativa } \\
\text { - Incorporação de agentes privados a } \\
\text { novas áreas de infra-estrutura }\end{array}$ & $\begin{array}{l}\text { - Diminuição no esforço de } \\
\text { investimento inversor em } \\
\text { setores dinâmicos } \\
\text { - Diminuição esforço } \\
\text { investidor em setores de } \\
\text { exportação } \\
\text { - Venda de empresas de } \\
\text { grupos econômicos a } \\
\text { transnacionais } \\
\text { - Reconcentração do } \\
\text { capital em sectores de alta } \\
\text { rentabilidade e baixo nível } \\
\text { tecnológico }\end{array}$ \\
\hline
\end{tabular}

FONTE: Moguillansky, 1999, p. 291 


\section{Notas finais}

O desempenho das exportaçóes chilenas contribuiu para o crescimento da economia, melhorou o balanço de pagamentos e ampliou a capacidade de importação de insumos e bens de capital. Contudo, não há evidências de que as exportaçóes tenham estimulado o progresso tecnológico na escala esperada.

Houve importante diversificação das exportações, diminuiu muito a dependência em relação ao cobre e o país se tornou líder na exportação de produtos não tradicionais, como frutas frescas, produtos florestais, salmão em fazendas e produtos do mar. Aumentou muito o número de países de destino e de empresas exportadoras, mas as vendas estáo concentradas ainda em poucos mercados, poucos produtos e em número reduzido de empresas. Os novos setores exportadores são ainda muito dependentes de recursos naturais e com reduzido valor adicionado, o que mantém a dependência frente às flutuaçóes do preço das commodities.

La especialización en recursos naturales se ha convertido en un prolífico campo de discusión con respecto a las estrategias y políticas más aconsejables, puesto que a estas exportaciones se asignan varias características "no deseadas". Entre tales características diversos analistas han hecho referencia a su bajo valor agregado y uso de tecnologías simples, vulnerabilidad a los shocks externos, pocos encadenamientos intersectoriales, salarios bajos, efectos ambientales no deseados y poca capacidad de generación de empleo. Diversos argumentos matizan estas apreciaciónes, tanto con experiencias concretas en sentido contrario, como por la necesidad reconceptualizar o reevaluar algunos indicadores (...). De modo que, de esta discusión, surgen importantes elementos para la formulación de reorientaciones estratégicas, que eran necesarias antes de la crisis asiática y con mayor razón después de ella. (SILVA, 2001, p. 11)

A demanda internacional por algumas categorias de produtos com alto ou médio conteúdo tecnológico, e também por alguns produtos de origem natural em estágio avançado da cadeia de valor adicionado, tem crescido muito mais rapidamente do que a demanda por produtos de baixo conteúdo 
tecnológico e produtos de origem natural com baixo grau de processamento. Apesar da abundância de recursos naturais que o Chile possui, o país deve tentar produzir e exportar produtos mais elaborados:

[...] as assimetrias existentes na estrutura das parcelas de mercado entre os produtos de demanda dinâmica e os de demanda lenta dificilmente podem ser creditadas passivamente ao fato de que a América Latina é mais rica em recursos naturais do que o Leste Asiático, e que "inesperadamente" esses produtos caracterizam-se por uma demanda fraca nos mercados da OCDE. (PALMA, 2005, p. 423)

A diversificação das exportações é também desejável por outras razões:

Al ascender por la "escala tecnológica" con la diversificación de las exportaciones una economía puede elevar sus salarios reales, con lo cual estimula aún más el crecimiento y mejora la distribución del ingreso. Pero éste no ha sido en absoluto el caso de la economía chilena en el último par de decenios. Aunque las exportaciones se han diversificado, con pocas excepciones, su contenido tecnológico sigue siendo muy poco sofisticado, y los salarios siguen siendo mucho más bajos que los de países industrializados avanzados. (AGOSIN, 1999, p. 82)

No que diz respeito ao desenvolvimento das indústrias hacia atrás y hacia adelante, para haver outros casos de sucesso como o dos salmões, é necessário que o desenvolvimento das exportaçóes primárias favoreça a expansão de novas atividades produtivas. Por um lado a interação entre escalas de produção e tamanho dos mercados externos favorece a redução de custos das indústrias situadas hacia adelante. Isso explica sobretudo a expansão das commodities industriais. Por outro lado, a atividade primário exportadora incrementa a demanda por insumos que por sua vez favorecem o estabelecimento de indústrias e/ou atividades situadas hacia atrás a uma escala econômica viável. Para alguns autores, no Chile este fenômeno tem sido menos importante do que o anterior, mas facilitou a expansão da produção de equipamentos e bens de capital, bem como o desenvolvimento de serviços de engenharia para a produção mineral, pesqueira e florestal. 
As exportaçóes têm sido um dos fatores principais do crescimento econômico chileno, mas a diversificação para bens e serviços mais elaborados apresenta requisitos de política bem mais complexos, com maior articulação entre os setores privado e público.

O Estado teve participação ativa no crescimento da economia chilena, orientando os estímulos para o investimento em direção a determinados agentes e setores. Além disso, o Estado regulou de maneira efetiva a evolução dos mercados estratégicos (taxa de juros, taxa de câmbio, salário mínimo, bandas de preços agrícolas e tarifas públicas), visando provocar uma modificação estrutural dos preços relativos, a fim de criar um ambiente mais favorável para as empresas exportadoras. Entre os agentes mais beneficiados pelas açóes do Estado destacam-se os grandes grupos econômicos, o capital estrangeiro e as grandes e médias empresas. Registre-se que, apesar da ampla privatização, a maior produtora de cobre do Chile, a Codelco, continua nas mãos do Estado e é importante fonte de recursos para o setor público.

Com o ProChile, o Estado tem conseguido promover a exportação de mercadorias e serviços, ajudando principalmente os pequenos e médios produtores, que têm dificuldade em obter informaçóes adequadas sobre as tecnologias para produzir os serviços que podem ser vendidos no mercado externo, os canais de distribuição e comercialização nos mercados externos e os gostos do consumidor e as necessidades dos produtores nos mercados potenciais. Realmente, empresas beneficiadas pelo ProChile, em média exportam mais, tanto em valor quanto em número de produtos, em relação às empresas não beneficiadas. Além disso, os resultados do estudo indicam que a utilização dos instrumentos de promoção gera impacto positivo e significativo no número dos mercados de exportação. 


\section{Referências Bibliográficas}

AGOSIN, Manuel. Comercio y crecimiento en Chile. Revista de la CEPAL, Santiago de Chile, v. 68, p. 79-100, ago. 1999.

ALVAREZ, Roberto. Desempeño exportador de las empresas chilenas: algunos hechos realizados. Revista de la CEPAL, Santiago de Chile, v. 83, p. 121134, ago. 2004.

. Inversión extranjera directa en Chile y su impacto sobre la productividad. Santiago, 2002.

ALVAREZ, Roberto; CRESPI, Gustavo. Impacto de las políticas de fomento sobre el dinamismo exportador chileno. El Trimestre Económico, México D.F., Fondo de Cultura Económica, v. 67 (4), n. 268, jul. 2000.

ALVAREZ, Roberto; FUENTES, Rodrigo. Trade reforms and manufacturing industry in Chile. Working Paper, n. 210, May. 2003.

ALVAREZ, Roberto; LEMUS, Anthony. ¿Se ha detenido el proceso de diversificación de las exportaciones chilenas durante los noventa? Estadística y Economía, Santiago de Chile, Instituto Nacional de Estadísticas (INE), n. 21, jun. 2001.

BANCO CENTRAL DO CHILE. Disponível em: http://si2.bcentral.cl/ Basededatoseconomicos/951_417.asp?m=BP_102\&f=A\&i=E. Acesso em: 15 jul. 2005.

BANCO MUNDIAL. Disponível em: www.worldbank.org. Acesso em: 13 mar. 2006.

BENEVANTE, José Miguel. Nuevos problemas y oportunidades para el desarrollo industrial de América Latina. Série Desarrollo Productivo, Santiago, CEPAL, n. 44, 46 p., Jun. 1997.

BERNARD, Andrew; JENSEN, Bradford. Why some firms export. National Bureau of Economic Research (NBER), Cambridge, MA, Working Paper 8349, July. 2001. Disponível em: http://www.nber.org/paper/w8349. 
CARVALHO, Carlos Eduardo. Reformas tributárias recentes na Argentina, Chile e México: uma visão geral. In: MEYER, Arno (Org.). Finanças públicas: ensaios selecionados. Brasília: IPEA/FUNDAP, 1997, p. 305-365.

CASTILLO, Mario; ALVAREZ, Raúl. El liderazgo en las grandes empresas en Chile, Grandes empresas y grupos industriales latinoamericanos: expansión y desafíos en la era de la apertura y la globalización, Wilson Peres (coord.), México, D.F.. Siglo Veintiuno Editores, 1998.

CASTILLO, Mario; DINI, Marco; MAGGI, Claudio. Reorganización industrial y estrategias competitivas en Chile. In: . Estabilización macroeconómica, reforma estructural y comportamiento industria.l Estructura y funcionamiento del sector manufacturero latinoamericano en los años 90. Buenos Aires: Alianza, 1996, 664 p.

CEPAL. América Latina y el Caribe: políticas para mejorar la inserción en la economia mundial. Santiago de Chile: Fondo de Cultura Económica, 1998.

. Anuário Estatístico. Chile: 2004.

COCHILCO. Normativa ambiental del sector minero. 2004. Disponível em: http://www.cochilco.cl/desarrollo/nacional/normativa.asp Acesso em: 01 nov. 2005.

CUNHA, Patrícia H. F. A transição do regime de bandas cambiais para o câmbio flutuante: a experiência do Chile nos anos 90. São Paulo: PUCSP, Programa de Estudos Pós-Graduados em Economia Política, Texto para Discussão 01/06, 2006, 18 p.

DAMILL, Mario; FANELLI, José M.; FRENKEL, Roberto. Shock externo y desiquilibrio fiscal. La macroeconomia de América Latina en los Ochenta. Los casos de Argentina, Bolivia, Brasil, Colombia, Chile e México. Santiago: CEPAL, 1994, 264 p.

DIAZ, Álvaro. Chile: la industria en la segunda fase exportadora. Trayectoria histórica y desafíos para los 90. In: . Estabilización macroeconómica, reforma estructural y comportamiento industrial. Estructura y funcionamiento del sector manufacturero latinoamericano en los años 90. Buenos Aires: Alianza, 1996, 664 p. 
EDWARDS, Sebastian. The order of liberalization of the external sector in developing countries. Princenton Essays in International Finance 156, Princenton University, Princenton, NJ, 1984.

. Openness, trade liberalization, and growth in developing countries. Journal of Economic Literature, v. 31, n. 3, p. 1358-1393, Sept. 1993.

EDWARDS, Sebastian; LEDERMAN, Daniel. The political economy of unilateral trade liberalization: the case of Chile. National Bureau of Economic Research (NBER), Cambridge, MA, Working Paper 6510, Apr. 1998. Disponível em: http://www.nber.org/paper/w6510.

FFRENCH-DAVIS, Ricardo. Debty-equity swaps in Chile. Cambridge Journal of Economics, Salem, Massachusetts, Clearence Center, Inc., v. 14, n. 1, 1990.

. El impacto de las exportaciones sobre el crecimiento en Chile. Revista de la CEPAL, Chile, v. 76, p. 143-160, Apr. 2002a.

. Export Dynamism and Growth since the 1980s. In: Economic reforms in Chile: from dictatorship to democracy, Michigan, EUA: Michigan Press, 2002b, 263 p.

FFRENCH-DAVIS, Ricardo; LEIVA, Patricio; MADRID, Roberto. La apertura comercial en Chile: experiencias y perspectivas. Estudios de Politica Comercial, Nueva York, UNCTAD, n. 1, 1991.

FONTAINE, Juan Andrés. La construcción de un mercado de capitales: el caso de Chile. Washington, DC: The World Bank, 1996.

GARCÍA, Rigoberto. Cambios industriales en Chile 1973-1987. In: Economía y política durante el gobierno militar en Chile, 1973 1987. México, D.F.: Fondo de Cultura Económica, 1989, 294 p.

GLAUSER, Kalki. Comercio exterior y cambio estructural. Chile, 19681986. In: _. Economía y política durante el gobierno militar en Chile, 1973 1987, México, D.F.: Fondo de Cultura Económica, 1989. 294 p. 
GREGORIO, José. Productivity growth and disinflation in Chile. National Bureau of Economic Research (NBER). Cambridge, MA, Working Paper 10360, Mar. 2004. Disponível em: http://www.nber.org/paper/w10360.

GREGORIO, Jose; EDWARDS, Sebastian; VALDÉS, Rodrigo. Controls on capital inflows: Do they work? National Bureau of Economic Research (NBER). Cambridge, MA, Working Paper 7645, Apr. 2000. Disponível em: http://www.nber.org/paper/w7645.

HAUSMANN, Ricardo; HWANG, Jason; RODRIK, Dani. What you export matters. National Bureau of Economic Research (NBER). Cambridge, MA, Working Paper 11905, Mar. 2006. Disponível em: http://www.nber.org/ paper/w11905.

HOUNIE, Adela et al. La CEPAL y las nuevas teorías del crecimiento. Revista de la CEPAL, v. 68, p. 7-33, agosto. 1999.

JONES, Charles. Introdução à teoria do crescimento econômico. Rio de Janeiro: Editora Campus, 2000. 178 p.

LOPES, Renata R; CARVALHO, Carlos E. Acordos comerciais bilaterais como estratégia de inserção regional e internacional do Chile. In: ENCONTRO NACIONAL DA ABRI, 1., 2007, Brasília. Anais... Brasília: Associação Brasileira de Relaçóes Internacionais - ABRI, 2007.

MACARIO, Carla. Restructuring in manufacturing: case studies in Chile, Mexico and Venezuela. Santiago: CEPAL, Série Desarrollo Productivo, n. 44, 40p. agosto. 1998.

MACARIO, Carla. (Ed.). Export growth in Latin America. Bouder, Colorado, Lynne Rienner, 2000.

MARFÁN, Manoel. Nueva reforma tributaria. Colección Estudios CIEPLAN, Santiago de Chile, n. 13, jun. 1984.

MELLER, Patricio. El cobre y la generación de recursos externos durante el regimen militar. Collección Estudios CIEPLAN, Santiago de Chile, n. 24, p. 85-111, jun. 1988. 
. El cobre chileno y la política minera. Serie de Estudios Socio/Económicos, CIEPLAN, n. 14, 54 p., enero. 2003.

MOGUILLANSKY, Graciela. La inversión en Chile: ¡en fin de un ciclo en expansión? Santiago, Chile: Fondo de Cultura Económica, 1999. 361 p.

MOGUILLANSKY, Graciela; SALAS, Juan C.; CARES, Gabriela. Capacidad de innovación en industrias exportadoras de Chile: la industria del vino y la agroindustria hortofrutícola. Série Comercio Internacional, Santiago, Cepal, n. 79, 65 p., 2006.

PALMA, Gabriel. Gansos voadores e patos vulneráveis: a diferença da liderança do Japão e dos Estados Unidos, no desenvolvimento do sudeste asiático e da América Latina. In: FIORI, J. L. (Org.). O poder americano. Petrópolis: Ed. Vozes, p. 393-451, 2005.

PROCOBRE, 2007. Disponível: em: http://www.procobre.org/procobre/ acerca_del_cobre/economia_productores.html?cfA322F426=ECE3D006! YTQ5MTgwNjpzZWN1cmVoZGF1dGg6SG4mKLXppaDBE3bKNexA mg.

PROCHILE. 2003. Disponível em: http://206.49.217.77/servlet/NavigationSe rvlet?page $=$ articulo\&id_section $=710716 \mathrm{D} 700000098005404081 \mathrm{D} 2018 \mathrm{D}$ D\&id_ficha_categoria=0 Acesso em: 02 mai. 2005.

RODRIK, Dani. The global governance of trade as if development really mattered. United Nations Development Programme, out. 2001.

RUSSO, Vanessa. Adoção de regime de câmbio flutuante: notas sobre a experiência chilena. 2004. 111 f. Dissertação (Mestrado em Economia Política) Pontifícia Universidade Católica de São Paulo, São Paulo, 2004.

SAÉZ, S. Indicadores de las exportaciones chilenas: 1950-89. Santiago de Chile, Notas técnicas, n. 138, 1991.

SILVA, Verónica. Estrategia y agenda comercial chilena en los ańos noventa. Série Comercio Internacional, Santiago, Cepal, n. 11, 76 p., 2001. 
THIRLWALL, Anthony. The nature of economic growth an alternative framework for understanding the performance of nations. Cheltenham, UK, Edward Elgar, 2002, 111p.

VIGNOLO, Carlos. El crecimiento exportador y sus perspectivas bajo el modelo neoliberal chileno. Santiago, CED, marzo. 1983.

WORLD PERSPECTIVE MONDE. Université de Sherbrooke, 2007. Disponível em: http://worldperspective.usherbrooke.ca/bilan/servlet/BMT endanceStatPays $?$ langue $=$ en $\&$ codePays $=$ CHL\&codeTheme $=7 \&$ codeStat $=$ NE.EXP.GNFS.ZS\&compareMonde $=1$ 